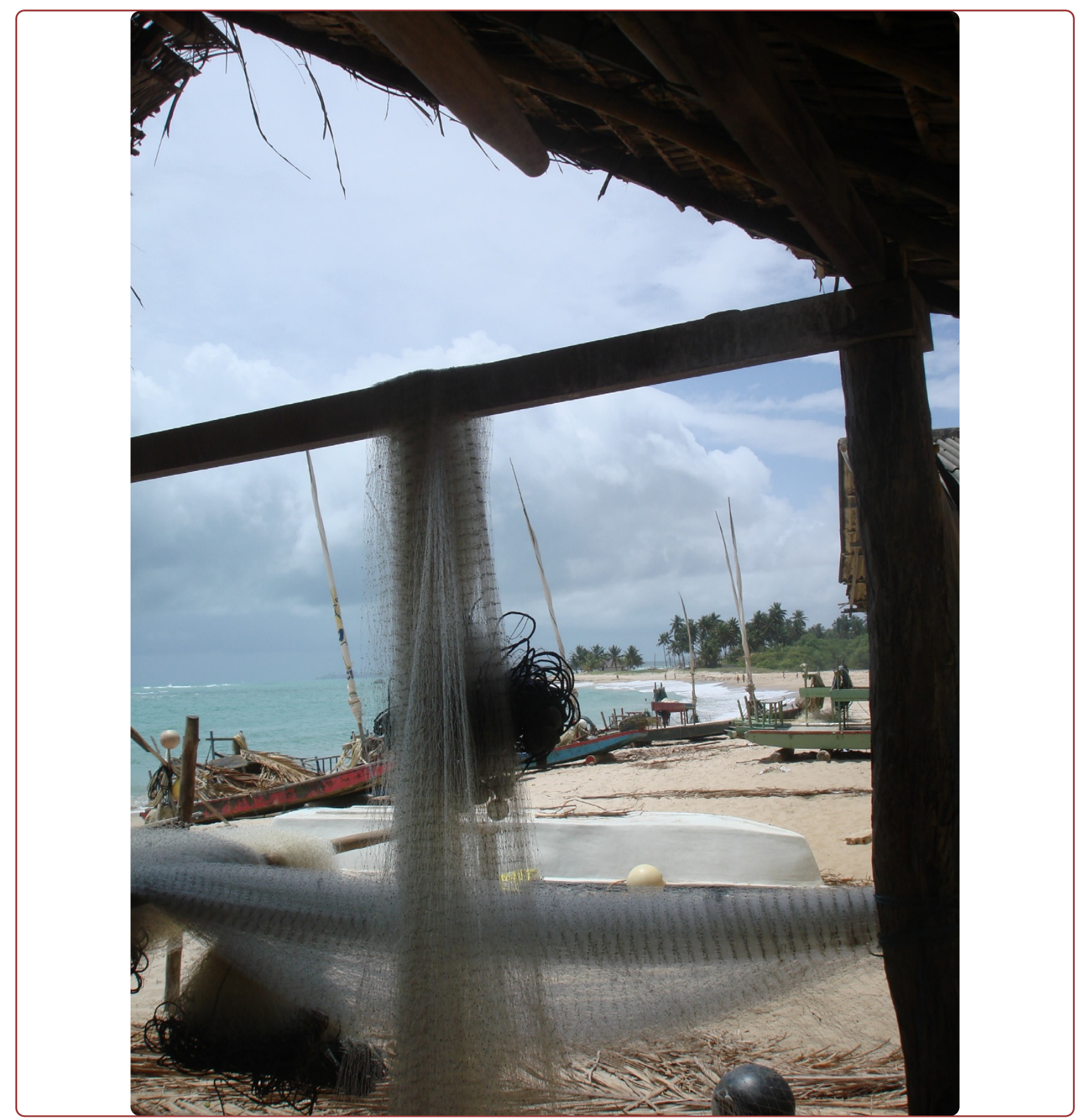

\title{
Ethnobiology of snappers (Lutjanidae): target species and suggestions for management
}

Begossi et al. 


\title{
Ethnobiology of snappers (Lutjanidae): target species and suggestions for management
}

\author{
Alpina Begossi ${ }^{1,2,3,4^{*}}$, Svetlana V Salivonchyk ${ }^{5}$, Luciana G Araujo ${ }^{1}$, Tainá B Andreoli ${ }^{1}$, Mariana Clauzet ${ }^{1,4}$, \\ Claudia M Martinelli', Allan GL Ferreira ${ }^{2}$, Luiz EC Oliveira ${ }^{1,6}$, Renato AM Silvano ${ }^{1,7}$
}

\begin{abstract}
In this study, we sought to investigate the biology (diet and reproduction) and ethnobiology (fishers knowledge and fishing spots used to catch snappers) of five species of snappers (Lutjanidae), including Lutjanus analis, Lutjanus synagris, Lutjanus vivanus, Ocyurus chrysurus, and Romboplites saliens at five sites along the northeast (Riacho Doce, Maceió in Alagoas State, and Porto do Sauípe, Entre Rios at Bahia State) and the southeast (SE) Brazilian coast (Paraty and Rio de Janeiro cities at Rio de Janeiro State, and Bertioga, at São Paulo State.). We collected 288 snappers and interviewed 86 fishermen. The stomach contents of each fish were examined and macroscopic gonad analysis was performed. Snappers are very important for the fisheries of NE Brazil, and our results indicated that some populations, such as mutton snapper (L. analis) and lane snapper (L. synagris), are being caught when they are too young, at early juvenile stages.

Local knowledge has been shown to be a powerful tool for determining appropriate policies regarding management of target species, and artisanal fishermen can be included in management processes. Other suggestions for managing the fisheries are discussed, including proposals that could provide motivation for artisanal fishermen to participate in programs to conserve resources, such as co-management approaches that utilize local knowledge, the establishment of fishing seasons, and compensation of fishermen, through 'payment for environmental services'. These suggestions may enhance the participation of local artisanal fishermen in moving to a more realistic and less top-down management approach of the fish population.
\end{abstract}

\section{Background}

Reef fishes of the Lutjanidae family (snappers) are important targets for fisheries in several regions worldwide, including Australia [1], the South Pacific [2], Africa [3,4], North and South America [5,6], and Brazil [7]. Snappers are locally called "Vermelhos" or "Pargos" in Brazil and are commonly exploited by artisanal fishermen $[7,8]$. There are about twenty-three genera of snappers (Lutjanidae) and the genus Lutjanus includes more than 70 species [9]; in http://www.fishbase.org[10] there are 173 scientific names listed for Lutjanus. In Brazil, there are twelve species of snappers from five genera: Etelis oculatus, Lutjanus analis, L. apodus, L. bucanella, L. cyanopterus, L. griseus, L. jocu, L. purpureus, L. synagris, L. vivanus, Ocyurus chrysurus, Pristipomoides freemani, P. aquilonaris and Rhomboplites aurorubens [11,12].

\footnotetext{
* Correspondence: alpinab@uol.com.br

${ }^{1}$ Fisheries and Food Institute (FIFO), UNISANTA, Santos, SP, Brazil

Full list of author information is available at the end of the article
}

Snappers have been intensively captured by marine fisheries on the northeastern Brazilian coast $[7,13,14]$, but these fishes have also been caught on the northeastern Brazilian coast by artisanal fisheries using mainly hooks and line and/or gillnets [15]. Snappers are carnivores, and species live in reef environments along the NE Brazilian coast at different depth ranges [16-20]. For example, at Porto Seguro, on the NE Brazilian coast, 38\% of 352 fish landings have caught snappers [8], a target also of the artisanal fisheries on the northeastern Brazilian coast [7]. Nevertheless, some species of snappers may have been overfished in Brazil. For example, Lutjanus purpureus has shown a decrease in the catch per unit of effort (CPUE); there was additionally a decrease in the weight and length of captured fish, indicating an increase in the capture of juvenile fish [21]. An analysis of the fishing time series of 1967-2000 indicated the vulnerability and local market extinction of snappers in two states (Rio Grande do Norte and Pernambuco) on the northeastern Brazilian coast [19]. Another study [22] indicated
() Biomed Central

() 2011 Begossi et al; licensee BioMed Central Ltd. This is an Open Access article distributed under the terms of the Creative Commons Attribution License (http://creativecommons.org/licenses/by/2.0), which permits unrestricted use, distribution, and reproduction in any medium, provided the original work is properly cited. 
that the yellow snapper, Ocyurus chrysurus, and the vermilion snapper, Romboplites aurorubens, which are two commercially important species for the Brazilian coast, have been overexploited. Most of the Brazilian fish production comes from artisanal fisheries [23]. Therefore is important to address the importance of artisanal fishing in tropical countries, especially in Brazil. Data from 2002 [15] showed that the contribution of artisanal fisheries to the total catch is $88 \%$ in NE Brazil, 34\% in SE Brazil, and that the contribution of artisanal fisheries has increased in SE Brazil since 1980.

The importance of managing fisheries resources has been emphasized, considering the current threat to marine resources [24-26]. Observing and measuring marine resources is costly [27], and there is an urgent need to obtain data on marine tropical fisheries [28]. Data are especially lacking for rocky and reef fishes that have slow growth and late reproductive maturity, including groupers and snappers [29]. This study was motivated by an urgent need to improve our understanding of the biology of snappers, and data were gathered based on the knowledge of the scientific community and that of local fishermen. These data may be useful for improving the local management of snappers. When paired with scientific knowledge (published literature), local knowledge could improve our understanding of high-biodiversity systems where basic biological information is lacking [30,31].

Studies that have combined scientific knowledge and the knowledge of local fishermen have been useful for enhancing the dialogue between resource users and managers. In some regions, such as tropical developing countries, these studies may be the only available source of knowledge about exploited fishing resources [28,32-34]. There is evidence that even artisanal fishing can impact fish populations, especially populations with late maturation and slow growth [35]. Reef fishes, including snappers, are among the fish species that are more vulnerable to fishing pressure [29]. The study of snappers in Brazil could be improved by including methods of ethnobiology, which is a discipline devoted to the survey of local ecological knowledge held by local people, including fishers [36,37].

The importance of using local fishermen's knowledge as a tool for fishery management has been acknowledged, analyzed and applied by a variety of researchers in many parts of the world, including the Pacific and small-scale Asian fisheries [38-45]. One study [46] applied both scientific and local knowledge to research and to the management of lobster fishing off the coast of Maine, USA, supporting an example of integrative management (co-management) where fishers are active participants in the lobster management. Another study [47] analyzed the definition of local knowledge and its implications for the management of several different extractive and agricultural communities in many parts of the world, including fisheries. In Brazil, local ecological knowledge related to small-scale fisheries has been studied by several authors [31,33,48-53]. Nevertheless, in Brazil, local, ecological knowledge of fishermen has not been fully applied to fisheries management, mainly because of misunderstandings on the part of environmental government agencies and biologists about of the importance of this information. Therefore, information gathered from fishermen can turn them active participants in management processes and it can be useful in places where there is lack of scientific data, such as many tropical fisheries.

Our results addresses the dialogue between scientific and local ecological knowledge $[32,33]$ by studying how snappers are being caught in the Brazilian coast, and by getting information on its diet and reproduction. An increased vulnerability of snappers on the coast of Brazil is observed, coupled with an urgent need for knowledge about their biology. The methods used here could be applied elsewhere, given the widespread exploitation of this vulnerable group of reef fishes.

The main objectives of our study were a) to record and analyze data on the snappers' reproductive period and diet through direct biological observations; b) to record and to analyze the same kind of data gathered by interviewing local fishermen; and c) to compare both sources of data (scientific and local knowledge) and suggest potential applications for improving snapper research and management; d) to suggest management of snappers through both scientific and local knowledge, using socialeconomical-ecological tools, such as co-management through fishing agreements and payments for environmental services.

\section{Study sites}

The five sites that were studied were located in northeastern ('Região Nordeste') and southeastern Brazil ('Região Sudeste-Sul') of the Brazilian Economic Exclusive Zone (EEZ) [54], as follows (Figure 1): Riacho Doce, Maceió, Alagoas State, and Porto Sauípe, Bahia State in northeastern Brazil; Paraty, and Copacabana (Rio de Janeiro city), Rio de Janeiro State, and Bertioga, São Paulo State in southeastern Brazil (Figure 1). The continental shelf is narrower in northeastern Brazil compared to the southern Brazilian coast, which implies that there are differences in artisanal fisheries. For example, on the northeast coast, fishermen work near the end of the continental shelf, locally called (in Porto Sauípe, Bahia) "paredão" (big wall). These fishermen can catch fish that are usually found in deeper waters, such as snappers, which are usually caught with hooks and lines on rafts ('jangadas'). The fisheries studied were artisanal fisheries that use small boats or 


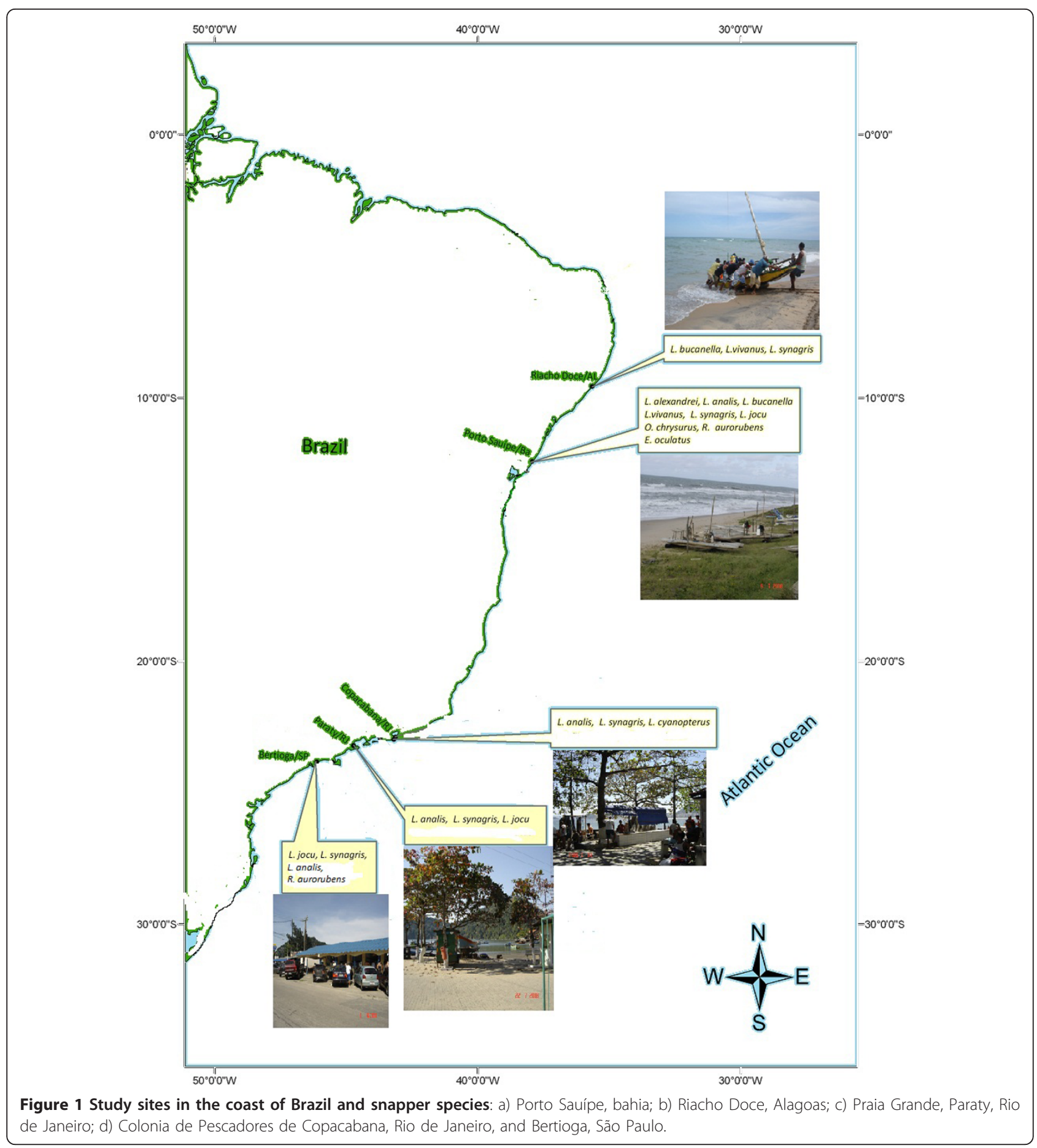

rafts and catch snappers mostly with hooks and lines, but some fisheries often use set gillnets.

\section{Northeastern Brazil}

\section{Riacho Doce}

Maceió, Alagoas State: This is a small community that is located close to other small fishing communities, such as Garça Torta, in the municipality of Maceió, the capital of Alagoas State. Riacho Doce is a tourist site where local fishermen divide their time among fishing tourism related activities and other jobs. Eleven fishers' rafts ('jangadas') and two fish stores, where fish are caught and sold, were observed in Riacho Doce.

\section{Porto do Sauípe, Entre Rios}

Bahia State: The village of Porto Sauípe is a small fishing community located in the municipality of Entre 
Rios, about $80 \mathrm{~km}$ from Salvador, the capital of the Bahia State. This village has about twenty-five fishermen listed in the Colonia de Pescadores Z-28 (a local fishermen's association), and about fourteen rafts ('jangadas') that are used for artisanal fishing were found in the villages.

\section{Southeastern Brazil}

\section{Paraty, Rio de Janeiro State}

The municipality of Paraty includes approximately thirteen small-scale artisanal fishing communities from the northernmost part of Tarituba to the southernmost part of Trindade [55]. The community includes about eleven local fishermen. Fishermen from nearby Araújo Island land usually fish at Praia Grande [55].

\section{Copacabana Beach, Rio de Janeiro, Rio de Janeiro State} Copacabana beach has one of the oldest artisanal fishing communities in Rio, which is associated at the Colonia Z-13 [56]. Based on earlier research projects [36,48,49], we estimated that about twenty-five fishermen frequently land their catches at Copacabana beach.

\section{Bertioga, São Paulo State}

Bertioga, which can be easily reached through the RioSantos highway, is a small city that includes about twenty-five fishermen. Bertioga has been a part of earlier projects describing the ethnobiology of artisanal fisheries $[36,53,57,58]$.

All of the Brazilian artisanal fisheries described above commonly sell and catch many fish species, including bluefish (Pomatomus saltatrix, Pomatomidae), cutlassfish (Trichiurus lepturus, Trichiuridae), mackerels (Scomberomorus spp., Scombridae), mullets (Mugil spp., Mugilidae), groupers (Epinephelus spp. and Mycteroperca spp., Serranidae), snooks (Centropomus spp., Centropomidae), weakfishes (Cynoscion spp., Sciaenidae), as well as rays, sharks (many species of Chondrichthyes) and many other species. We previously observed that snappers are very common in the fishery of Porto Sauípe, Bahia compared to the other sites that were studied.

\section{Methods}

At Riacho Doce the local fishermen estimated that about twenty artisanal fishermen live in Riacho Doce. The snappers were sampled in the 'Peixaria do Haroldo' (fish market). At Porto do Sauípe we interviewed twenty-two artisanal fishermen in this village during a project conducted in 2005 and this data set was used as a baseline for the current study. Ethnobiological data about coastal fishes are available for this village and adjacent fishing communities [36,53]. The snappers were sampled in the 'Peixaria do Chico' (a small fish market). Local fishers used hooks and line to catch snappers at depths of about 165-220 m (75-100 'braças', a local measurement adopted by fishers). In Paraty, we studied the snappers and the fishermen that land their catches in the fishing community of Praia Grande, close to Araújo Island. Our study of fishermen and snappers was performed especially at the 'Peixaria do Sinésio' (a small fish market), located at Praia Grande, among other fish stores from Paraty. At Rio de Janeiro, our study of fishermen and snappers was carried out at the local landing point, where fishermen and middlemen sell their catch directly to consumers. At Bertioga, our research was conducted at the main fish market and landing point. We collected snappers mainly at two small stores in this fish market (Figure 1).

All snapper species were obtained from fish landed by fishermen, mostly between April and November of 2008. L. analis was collected mainly from April to July in Copacabana, Rio de Janeiro, with a similar pattern observed for L. synagris in Bertioga, SP.

Complementary methods were used to collect data on snapper biology and ethnobiology:

\section{1) Sampling of snapper stomachs and gonads}

During each trip to the studied fishing communities (described above), we searched for the landing/market point where fishermen landed snappers. All of the available snappers that were found in these landing points/ markets were sampled by either buying the fish (which was then opened up for analysis) or its contents (viscera). Each sampled fish was weighed (g) and measured for total length (TL) (mm). The gonads (volume) were measured in milliliters $(\mathrm{ml})$ and visual inspections were conducted to document the gonads' color and the presence or absence of visible eggs (macroscopic analyses). These procedures followed methods detailed in earlier studies [33], which have been used for other coastal fish species[36,37].

Based on gonad volume, regardless of the presence of visible eggs or sperm, the measurements from 288 fish were collected and used to calculate the gonadossomatic index (GSI) for 241 snappers. This index was calculated based on a classic formula [58] and used in studies on artisanal fishers [37] as: (GSI = [gonads weight/body weight] $\times$ 100). The weight of the fish gonad was defined by its volume, assuming the average density of fish flesh was 1.065. The volume data were standardized, and gonads with less than $1 \mathrm{ml}$ of volume were considered to be equal to $0.5 \mathrm{ml}$. Seasonal differences in the fish GSI were investigated with a non-parametric Kruskall-Wallis test.

\section{2) Field trips}

the number of field trips to collect data was different for each study site, but monthly trips were performed to Bertioga and Copacabana, SE Brazil. For the NE Brazil areas, we made a total of three field trips; one to Riacho Doce and two to Porto do Sauípe. Although the second trip to Porto do Sauípe was not planned in our project, 
this trip was made necessary based on information provided by the fishermen about the spawning period of snappers. The goal of the trip was to double check the gonad maturation season of the studied snapper species (the second trip occurred in October 2008, Table 1). The number of days and of collection of snappers fieldtrips varied as a function of the distance of the field sites from our main institutions (first author). For far places, such as Alagoas and Bahia, we had to concentrate data collection in one or two trips. For nearby places, such as Rio and Bertioga, we could perform monthly visits. Paraty was included later, as a way to compare data between Copacabana (Rio) and Bertioga, an in-between site.

\section{3) Interviews}

interviews with fishermen were based on standardized questionnaires with a few questions about snappers, such as their occurrence at the study site, their diet and their period of reproduction. The interviewed fishermen were selected based on previous interviews from earlier projects in Bertioga, Porto Sauípe and Copacabana beach [36,37]. In the other study sites (Riacho Doce and
Paraty), fishermen were opportunistic selected at the landing points. Interviews were done with full-time, skilled fishermen who had lived at the sites for at least ten years.

\section{4) Identification of the fish and stomach contents}

The collected snappers were identified in the field using identification keys $[10,11,59]$, as well as Plates I-V from Western Atlantic, Fishing areas 31 and 41 (ftp://ftp.fao. org/docrep/fao/009/ac481e/AC481E49.pdf). Visible food items found in the stomach of the snappers were collected for identification at Capesca (Unicamp) using taxonomic keys $[11,12,60]$. Identifications of fish found in the snappers' stomachs contents of snappers were made by experts in the field from MZUSP (fish: R. Caires and J. L. Figueiredo; crabs and shrimp: G.S. Melo).

\section{5) Weight-length relationships}

The relationships between weight and length were calculated for all collected snapper species, in $\mathrm{g}$ and $\mathrm{mm}$, respectively. These relationships were described by second-order polynomials. A linear approximation of the Weight-Total Length (W-TL) relationships did not seem

Table 1 Snappers (Lutjanidae) sampled in 2008-2009 in the Brazilian coast

\begin{tabular}{|c|c|c|c|c|c|c|c|c|c|c|c|c|c|}
\hline \multirow{3}{*}{ Site } & \multirow{3}{*}{ Species } & \multicolumn{10}{|c|}{ Season/Month } & \multirow{3}{*}{\multicolumn{2}{|c|}{ Total }} \\
\hline & & \multicolumn{2}{|c|}{ Autumn } & \multicolumn{3}{|c|}{ Winter } & \multicolumn{3}{|c|}{ Spring } & \multicolumn{2}{|c|}{ Summer } & & \\
\hline & & AP & MY & JU & J & $\mathrm{AU}$ & SE & OC & NO & $\mathrm{DE}$ & JA & & \\
\hline \multirow[t]{4}{*}{ Bertioga } & L. analis & & 2 & 1 & & & & & & & & 3 & \\
\hline & L. jocu & 1 & 2 & & 3 & & & & & & & 6 & 44 \\
\hline & L. synagris & & 4 & 15 & & 3 & 5 & & & 2 & & 29 & \\
\hline & R. aurorubens & & & 6 & & & & & & & & 6 & \\
\hline \multirow[t]{3}{*}{ Maceio $^{1}$} & L. buccanella & & & & & & & & & & 5 & 5 & \\
\hline & L. synagris & & & & & & & & & & 15 & 15 & 28 \\
\hline & L. vivanus & & & & & & & & & & 8 & 8 & \\
\hline \multirow[t]{3}{*}{ Paraty } & L. analis & & & & & 5 & & & 4 & & & 9 & \\
\hline & L. jocu & & & & & & & & 1 & & & 1 & 44 \\
\hline & L. synagris & & & & & 3 & & & 31 & & & 34 & \\
\hline \multirow[t]{9}{*}{ Porto Sauípe } & E. oculatus & & & & 2 & & & & & & & 2 & \\
\hline & L. analis & & & & & & & 1 & & & & 1 & \\
\hline & L. alexandrei & & & & 7 & & & & & & & 7 & \\
\hline & L. buccanella & & & & 5 & & & 2 & & & & 7 & \\
\hline & L. jocu & & & & 1 & & & & & & & 1 & 137 \\
\hline & L. synagris & & & & 7 & & & 1 & & & & 8 & \\
\hline & L. vivanus & & & & 14 & & & 15 & & & & 29 & \\
\hline & O. chrysurus & & & & 57 & & & 9 & & & & 66 & \\
\hline & R. aurorubens & & & & 4 & & & 12 & & & & 16 & \\
\hline \multirow[t]{3}{*}{ Copacabana } & L. analis & 8 & 9 & 3 & 5 & & 1 & 4 & & 2 & & 32 & \\
\hline & L. cyanopterus & & 1 & & & & & & & & & 1 & 35 \\
\hline & L. synagris & & & 2 & & & & & & & & 2 & \\
\hline \multirow{2}{*}{\multicolumn{2}{|c|}{ Sub-total Total }} & 9 & 18 & 27 & 105 & 11 & 6 & 44 & 36 & 4 & 28 & & \\
\hline & & \multicolumn{2}{|c|}{27} & \multicolumn{3}{|c|}{143} & & 86 & & \multicolumn{2}{|c|}{32} & \multicolumn{2}{|r|}{288} \\
\hline
\end{tabular}

${ }^{1}$ Riacho Doce, Maceió: one L. analis was observed, but not collected. 
informative because this procedure assumed de facto that the mass of a fish was linearly proportional to its length. While this assumption may hold true for some length intervals, it fails for the whole range of lengths. In this study, therefore, the approximation made with the second degree polynomial provided a much better fit than the linear one (we explored the possibilities of a better fit by comparing the determinacy coefficients $R^{2}$, for different fits).

\section{Results}

\section{Snapper species caught by fishermen}

A total of 288 snappers were collected and 86 fishermen were interviewed over 142 days of fieldwork from April 2008-January 2009 in the five studied fishing communities (Table 1). These collected snappers belonged to four genera and ten species of Lutjanidae (seven species are from the genera Lutjanus) (Table 2). About 90\% of the total number of snappers collected belonged to just five species of Lutjanidae: Lutjanus analis (45 individuals), Lutjanus synagris (88), Lutjanus vivanus (37), Ocyurus chrysurus (66) and Rhomboplites aurorubens (22). Among those fishes collected in Bertioga and at Riacho Doce, Maceió, the species Lutjanus synagris (66 and $54 \%$ of individuals caught, respectively) was predominant. In Copacabana, Lutjanus analis (91\%) was predominant, while in Porto Sauípe the most frequently caught species were Ocyurus chrysurus (48\%), Lutjanus vivanus (21\%) and Rhomboplites aurorubens (12\%) (Table 2). A greater diversity of snapper species was found in the fish landings of the fishing community at Porto do Sauípe, Bahia (Table 2, Figure 1).

The seasonal occurrence of the five snapper species (L. analis, L. synagris, L. vivanus, O. chrysurus and $R$. aurorubens), based on collections during the whole year, was as follows: 21 individuals were collected in autumn (April-May), 104 in winter (June-August), 77 in spring (September-November), and 32 in the summer (December-January). In Bertioga and Copacabana, snappers were collected during the whole year, while in Porto Sauípe, they were collected only in the winter and spring. In Maceió, the collection was made only in the summer and in Paraty, the collection was made only in the winter and spring (Table 1).

The five most collected snapper species were analyzed in detail below. They are listed in order from the most individuals to the least individuals collected (Table 2 and Figures 2,3,4,5, and 6):

\section{Lutjanus synagris (Linnaeus, 1758)}

A total of 88 lane snappers (L. synagris), locally called 'vermelho-ariocó', were sampled in all of the five studied fishing communities. However, $89 \%$ of the sampled fish were collected in Bertioga (SP), Paraty (RJ), (SE Brazil) and Riacho Doce (NE Brazil) (Table 2). Lane snapper was associated with reefs, and this species formed large reproductive aggregations and fed on small fishes, crabs, shrimps, worms, and gastropods, among other things [10]. The identification of lane snappers was based on the presence of ten spines and twelve rays on the dorsal fin, along with a silvery-reddish body color, longitudinal yellow stripes and a diffuse black spot above the lateral line [11] (Figure 2). Additional information obtained recently in a current project confirmed the relative importance of lane snapper, amongst the other snapper species, in landings of artisanal fisheries in Praia Grande (Paraty).

\section{Ocyurus chrysurus (Bloch, 1791)}

66 yellowtail snappers (O. chrysurus) were collected in Porto do Sauípe, NE Brazil, mainly in July 2008 (86\%)

Table 2 The most caught snappers in the study sites in Brazil

\begin{tabular}{|c|c|c|c|c|c|c|c|c|}
\hline Period & $\begin{array}{l}\text { L. analis, } \\
\text { Copacabana }\end{array}$ & $\begin{array}{l}\text { L. synagris, } \\
\text { Bertioga }\end{array}$ & $\begin{array}{l}\text { L. synagris, } \\
\text { Maceió }\end{array}$ & $\begin{array}{l}\text { L. vivanus, } \\
\text { P. Sauipe }\end{array}$ & $\begin{array}{l}\text { O. chrysurus, } \\
\text { P. Sauipe }\end{array}$ & $\begin{array}{l}\text { R. aurorubens } \\
\text { P. Sauipe }\end{array}$ & $\begin{array}{l}\text { L. synagris, } \\
\text { Paraty }\end{array}$ & Total \\
\hline April & 8 & & & & & & & 8 \\
\hline May & 9 & 4 & & & & & & 13 \\
\hline June & 3 & 15 & & & & & & 18 \\
\hline July & 5 & & & 14 & 57 & 4 & & 80 \\
\hline August & & 3 & & & & & 3 & 6 \\
\hline September & 1 & 5 & & & & & & 6 \\
\hline October & 4 & & & 15 & 9 & 12 & & 40 \\
\hline November & & & & & & & 31 & 31 \\
\hline December & 2 & 2 & & & & & & 4 \\
\hline January & & & 15 & & & & & 15 \\
\hline Autumn & 17 & 4 & & & & & & 21 \\
\hline Winter & 8 & 18 & & 14 & 57 & 4 & 3 & 104 \\
\hline Spring & 5 & 5 & & 15 & 9 & 12 & 31 & 77 \\
\hline Summer & 2 & 2 & 15 & & & & & 19 \\
\hline
\end{tabular}




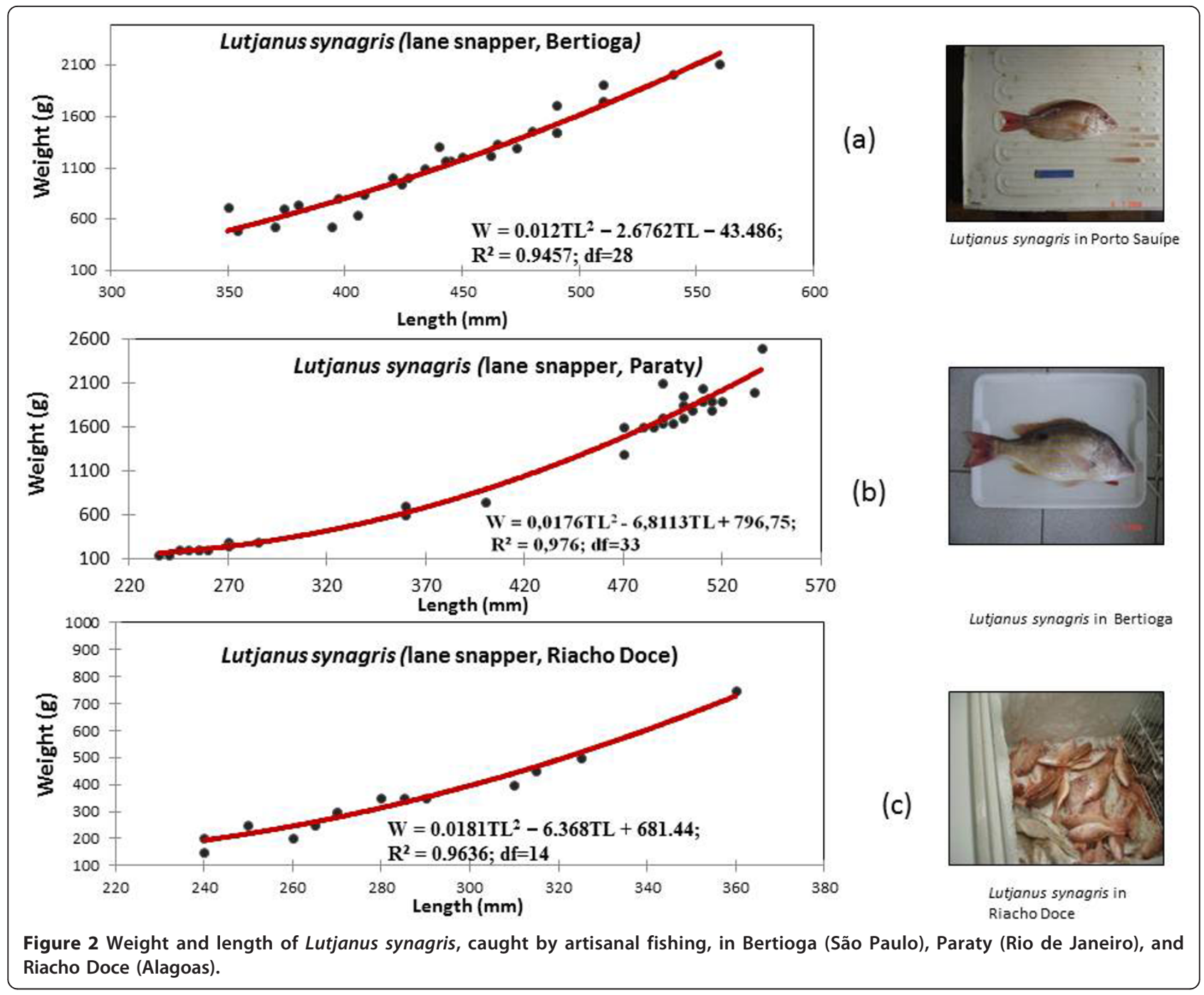

(Table 2). Yellowtail snapper is locally called 'vermelhoguaíba' or just 'guaíuba'. This fish is a reef species, which lives in coastal waters and formed aggregations. The yellowtail snapper feeds on fish, crustaceans, worms, gastropods and cephalopods [10]. The dorsal fin has ten spines and twelve to thirteen rays as well as a body with a yellow band that goes to the caudal fin [11] (Figure 3).

\section{Lutjanus analis (Cuvier, 1828)}

Most of the 45 mutton snappers (L. analis), which were locally called "vermelho-cióba" or "cióba", were collected in Copacabana beach, Rio de Janeiro (71\%) in 2008. At other sites, this fish was collected mostly in the autumn and winter seasons, especially at the sites of Bertioga, Paraty, and Porto do Sauípe (Table 2). Mutton snapper, which is now considered to be a vulnerable species by the UICN red list, lives in the continental shelf close to islands, forms small aggregations, and feeds on fish, shrimps, crabs, cephalopods, and gastropods [10]. Its body has a dorsal fin with ten spines and fourteen rays. It has a lateral black spot below the first rays of the dorsal fin as well as pale-blue stripes below the eyes [11] (Figure 4).

\section{Lutjanus vivanus (Cuvier, 1828)}

The silk snapper, L. vivanus, was collected in NE Brazil, mainly at Porto do Sauípe in Bahia State (78\% of 37 fish). This fish is locally called true snapper" ('vermelho-verdadeiro', or 'vermelho-legítimo', or 'vermelho-comum', or 'vermelho-original') in Porto do Sauípe. This fishing site has a relatively narrow continental shelf, allowing fishermen to use hook and line at large depths, which probably helps them catch silk snappers, named as a "reference fish" (prototype) within the local nomenclature of snappers. This fish is abundant around the Antilles and the Bahamas [10]. The species is common on shelves, but it can be found in water deeper than $200 \mathrm{~m}$. Silk snappers feed on fish, shrimps, crabs, and other invertebrates. It reaches about $500 \mathrm{~mm}$ in size, has ten dorsal spines and 


\section{Ocyurus chrysurus, Porto do Sauípe}
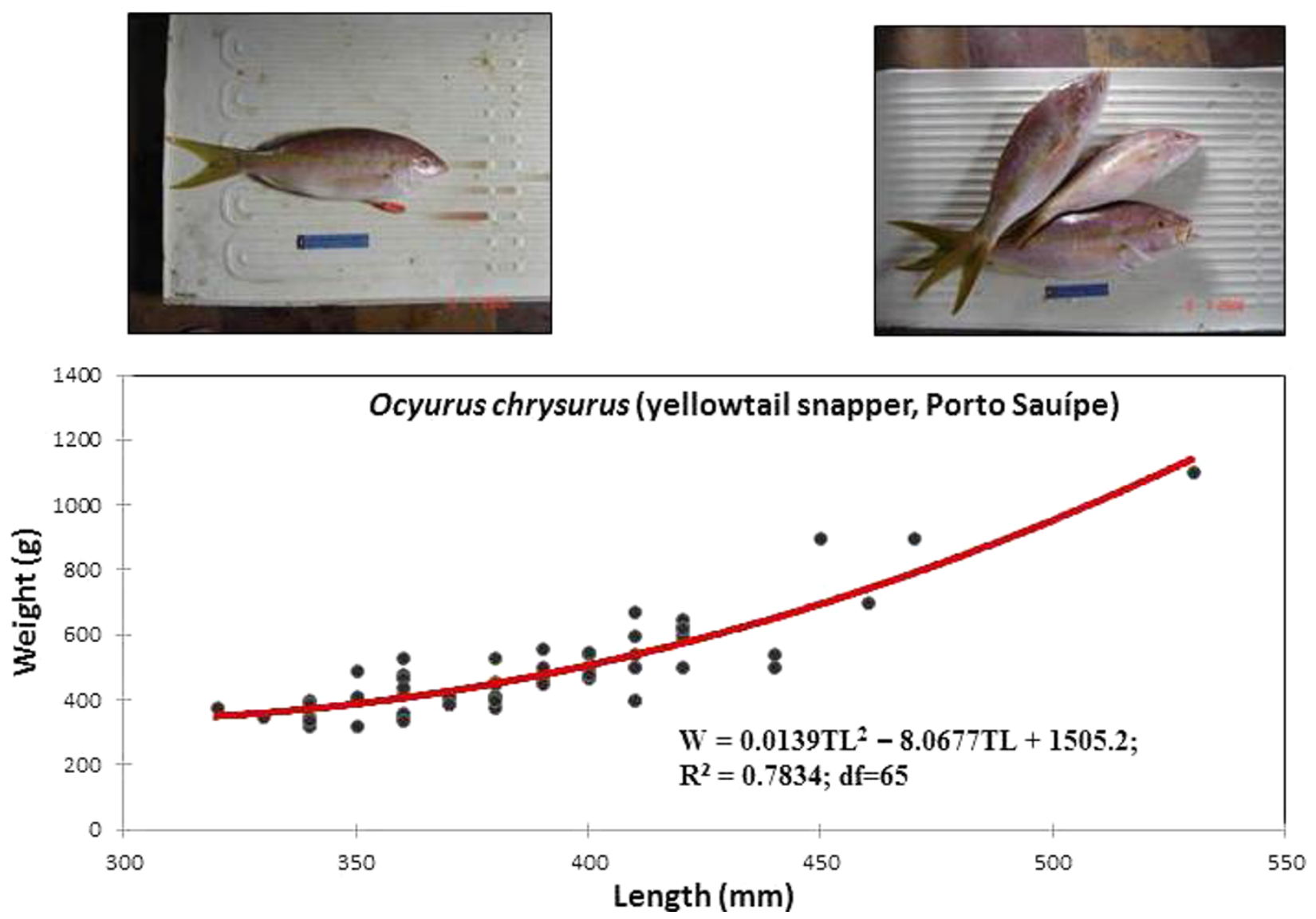

Figure 3 Weight and length of Ocyurus chrysurus, caught by artisanal fishing, in Porto Sauípe (Bahia).

fourteen rays in its dorsal fin, and a reddish body color [11]. Local fishermen in Porto do Sauípe, Bahia consider the yellow pigment in its iris to be a typical feature of this fish species (Figure 5).

\section{Romboplites aurorubens (Cuvier, 1829)}

The vermilion snapper ( $R$. aurorubens), which is locally called 'vermelho-prumirim' or 'paramirim', is found, on rocks, gravel or sand [10]. This snapper species forms large schools and feeds on fishes, shrimps, crabs, and other invertebrates. It has twelve spines and ten to eleven rays on the dorsal fin. The body of the vermillion snapper is reddish with dark oblique stripes on its dorsal part and yellowish stripes can be seen below the lateral line (Figure 6).

The other snapper species that were collected included Etelis oculatus (Porto do Sauípe, Bahia), Lutjanus alexandrei. This fish was first identified in the field as $L$. apodus, but revised to $L$. alexandrei after pers. comm. by J. L. Figueiredo, and consultation to reference [59]. The fish was collected in Porto do Sauípe, Bahia,
Lutjanus cyanopterus (Copacabana, Rio de Janeiro), and Lutjanus jocu (Bertioga, Paraty and, Porto do Sauípe) (Table 2).

\section{Weight-length relationships of snapper}

Weight-length relationships were calculated for all collected snapper species and are described by second-order polynomials in Figures 2, 3, 4, 5 and 6. Among the collected snapper species, the greatest deviation from linearity was found for Lutjanus analis (Figure 2), and the smallest deviation was found for Lutjanus vivanus and Rhomboplites aurorubens (Figures 5 and 6). The precision of the approximations used for all of the presented experimental data was high, so one can assume that there is a strict functional relationship between fish weight and length. This trend was more evident in Lutjanus synagris and Lutjanus analis (Figures 2 and 4). The largest difference in weights that corresponded to the same fish length was observed for Ocyurus chrysurus (Figure 3).

The regression coefficients and values of the weightlength relationships for L. synagris suggested that body depth (or vertical length decreases as fish grow (Figure 2), 


\section{Lutjanus analis, Copacabana, Rio de Janeiro}
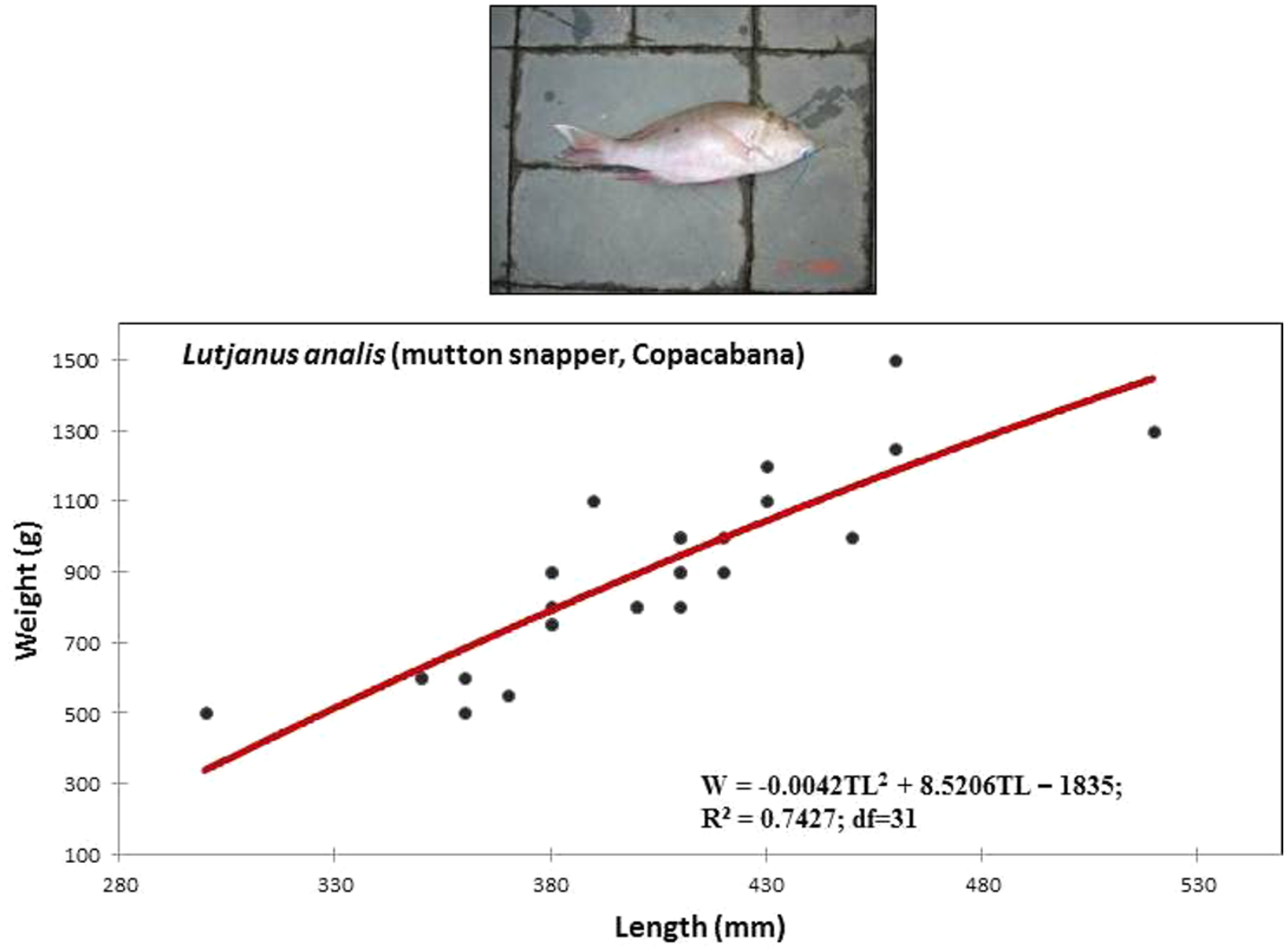

Figure 4 Weight and length of Lutjanus analis, caught by artisanal fishing, in Copacabana (Rio de Janeiro)

but this trend was not as steep as the trends for other species like Lutjanus griseus (Starck and Schroeder, 1971). We observed that the sizes of this fish species caught by fishermen from Bertioga, Paraty and Riacho Doce, Maceió ranged from $250-550 \mathrm{~mm}$ (maximum length is $600 \mathrm{~mm}$ TL [10]).

Samples of $O$. chrysurus included mostly fish landed by fishermen at the Porto do Sauípe. These fish had body lengths between 350-450 $\mathrm{mm}$ (the maximum length recorded was $863 \mathrm{~mm}$, [10]) (Figure 3). The mutton snappers, $L$. analis, which were caught by fishers in Copacabana, were between 350-450 mm (TL) (Figure 4). The silk snappers, L. vivanus, had a range of body lengths between 300-380 mm TL (Figure 5). The R. aurorubens that were caught were measured between 300 $350 \mathrm{~mm}$ in length (Figure 6). The seasonal length distributions of these snapper species are shown in Figures 7 and 8 . We observed the highest snapper patterns in length for the autumn and winter seasons.

\section{Reproduction: gonad analysis of snappers obtained from} fish landings

The analysis of fish gonads was possible only for five of the collected species, which were L. analis, L. synagris, L. vivanus, O. chrysurus, and $R$. aurorubens (Table 3 ). Visible eggs in the gonads of females were observed in autumn for L. analis, year-round for L. synagris, and in spring for L. vivanus, O. chrysurus and a few R. aurorubens individuals (Table 3 ). It appeared that most of the studied snappers reached sexual maturity during the spring (September-December) (Figure 7). The GSI values of the five most frequently caught snapper species showed some seasonal differences. For example, L. analis collected in Copacabana showed a higher GSI in summer than in spring. Additionally, L. synagris collected in Bertioga showed a higher GSI in summer than in winter (Table 3). Two snapper species collected in Porto Sauipe, L. vivanus and O. chrysurus, had higher GSI values in the spring than in the winter. 


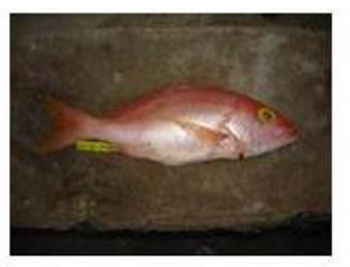

Lutjanus vivanus. Riacho Doce, Alagoas (the cut was made by a fisher in order to identify its catch)

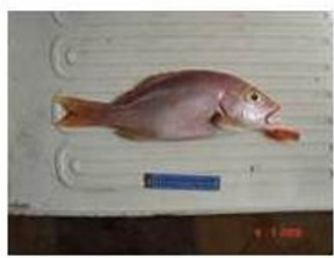

Lutjanus vivanus, Porto do Sauipe, Bahia

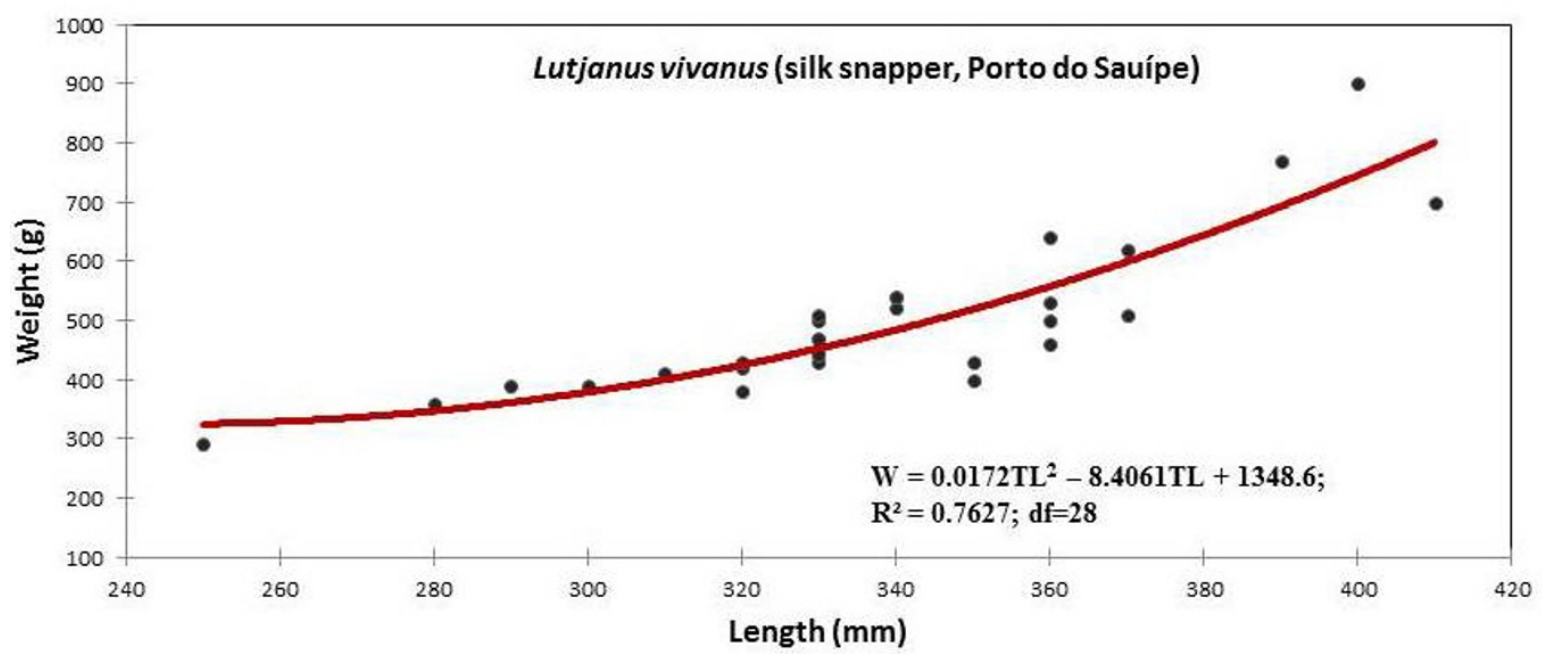

Figure 5 Weight and length of Lutjanus vivanus, caught by artisanal fishing, in Porto Sauípe (Bahia).

\section{Diet of snappers: stomach content analysis}

Out of 221 snappers from five species (L. analis, L. synagris, L. vivanus, O. chrysurus, and $R$. aurorubens), from the five studied sites, we found 95 fish with empty stomachs. Many of the fish with empty stomachs were caught in Porto do Sauípe, Bahia. Some fish in Bahia had their stomachs expelled out of their mouths, possibly due to the high depths at which they were caught with the fishermen's hooks. From 126 stomachs that were analyzed, $40 \%$ included fish and $42 \%$ had crustaceans (Table 4). With the exception of L. analis, in which fish was most commonly found in the stomach contents, the other species of snappers ate mostly crabs and shrimp (Table 4). Shrimp is a commonly used bait to catch snappers. Therefore, care should be taken not to overestimate its presence in the stomach contents of snappers caught from hook and line fishing.

Local knowledge: what do fishermen know about snappers? From a set of interviews that were previously performed in Bertioga, Copacabana, Paraty (SE Brazil), Porto do Sauípe, and Riacho Doce (NE Brazil) (Appendix 1), we selected a sub-sample of fishermen that lived at the study sites and had been fishing at that location for at least ten years. We interviewed a total of seventy fishermen. Their ages ranged between 40 and 60 years old, the number of years they had been fishing ranged between 22 and 48 years and the time they resided at the sites ranged between 27 and 59 years (Table 5).

Fish and shrimp is the diet most cited by fishermen for snappers. The fishermen said that snappers live in rocky substrates and spawn in the spring and summer (Table 5). The results from polling the local knowledge, and especially the comparative data for Porto Sauípe, showed that fishermen can very precisely determine the reproductive season of very common species caught in their locality, such as Lutjanus vivanus and Ocyurus chrysusrus (65-75\% of samples with visible eggs in October, 2008, Table 5).

Appendix 1 shown details on fieldwork and interviews (questionnaire and Table 6), on weight and length of the five common snapper species (Tables 7 and 8), on GSI and its statistics (Table 9 and 10), and a reference for the locations (fishing spots) where snappers are often caught by artisanal fishers from each fishing community (Table 11 in Appendix 1).

\section{Discussion}

\section{Size and maturity of snappers}

We observed that the five snapper species that were most frequently collected (Lutjanis analis, L. synagris, L. vivanus, Osciurus chrysurus, and Romboplites aurorubens) were caught at relative early stages of maturity, as exemplified by Figures 3, 4, 5, 6 and 7. L. analis, in 


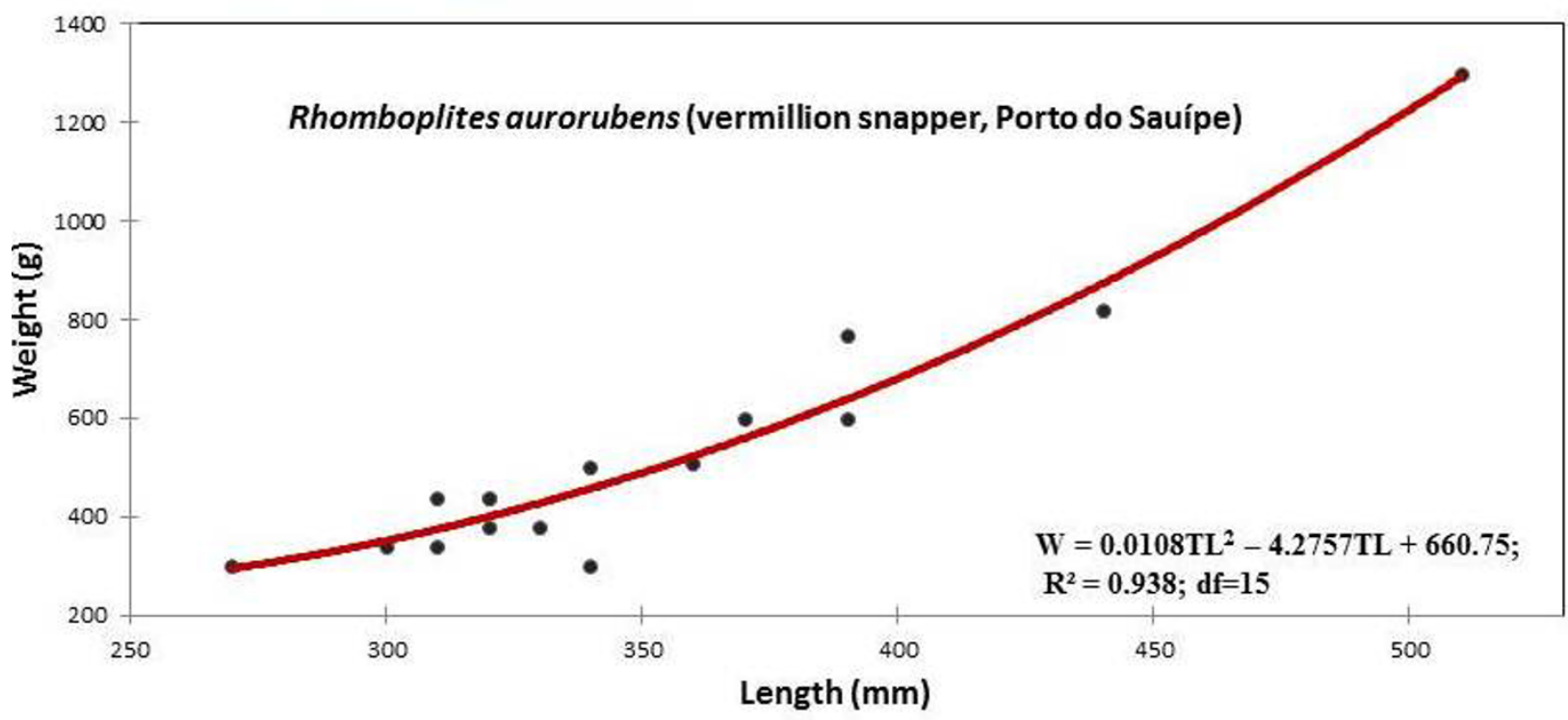

Figure 6 Weight and length of Romboplites aurorubens, caught by artisanal fishing, in Porto Sauípe (Bahia).

Copacabana, were caught between 350-450 mm; L. synagris, in Bertioga were caught between 350-450 $\mathrm{mm}$ and between 470-520 mm in Paraty, and in Riacho Doce, the fish were at sizes ranging between 240-300 $\mathrm{mm}$. L. vivanus, in Porto Sauípe, was caught between 300$400 \mathrm{~mm}$; Ocyurus chrysurus, in Porto Sauípe, was between 350-400 mm; and Romboplites aurorubens, in Porto Sauípe, ranged between 300-350 mm. The recorded length for maturity of those snapper species are recorded in Froese and Pauly (2010). The lengths for maturity are as follows: L. analis, $510 \mathrm{~mm}$; L. synagris, $236 \mathrm{~mm}$; L. vivanus $518 \mathrm{~mm}$; O. chrysurus, $245 \mathrm{~mm}$; and $R$. aurorubens, $200 \mathrm{~mm}$. Growth values $\left(\mathrm{L}_{\max }\right)$ for L. analis $(850 \mathrm{~mm})$, L. synagris $(650 \mathrm{~mm})$, and L. vivanus $(750 \mathrm{~mm})$ were found in NE Brazil [13]. This information reinforced the observation that while some of the studied local artisanal fisheries have been catching fish within a reasonable size, such as L. synagris in Bertioga and Paraty, different patterns occur at other sites. Those differences occurred for L. analis in Copacabana, for L. synagris in Riacho Doce and for L. vivanus in Porto Sauípe, which were caught before reaching maturity. In particular, the situation for L. analis is problematic because it is considered a vulnerable species [61].

Additionally, particular attention is needed for the species L. synagris, since there are other studies showing catches of snappers in juvenile stages in NE Brazil [14]. According to the cited study, artisanal fisheries using boats such as rafts ('jangadas'), and other small boats locally named 'paquetes', used in shallow waters, could be probably impacting populations of L. synagris. Our results reinforce this information, since our findings reveal that L. synagris was being caught too early, still in its juvenile stages (Figure 3 ) before maturity (236 mm) [10] in the shallow waters of Riacho Doce, Maceió. Such results might indicate overfishing (decreasing size of catches), but we still cannot determine whether the cause of that impact is derived from the local artisanal fishing or was a result of industrial fishing.

Knowledge on reproductive periods of species of snappers is an useful information towards fishery management. Results from interviews indicate that some fishermen know about the reproduction species (a half 


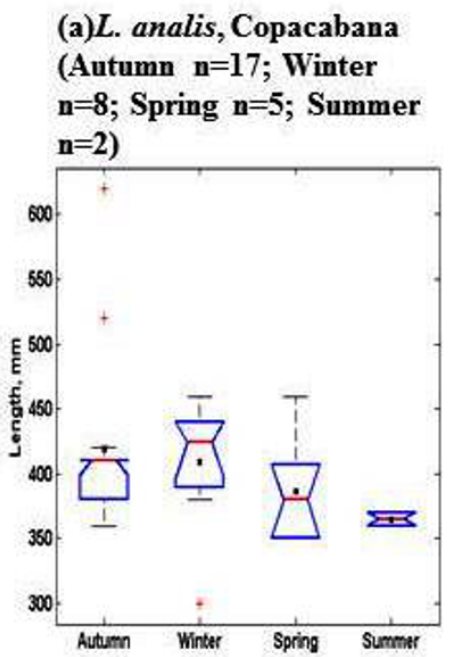

(c) L. vivanus, P. Sauipe (Winter $n=18$; Spring $n=5$ )

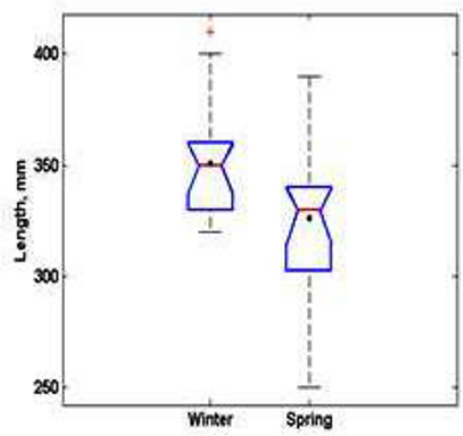

(e) R. aurorubens, P. Sauipe (Winter $n=4$; Spring $n=12$ )

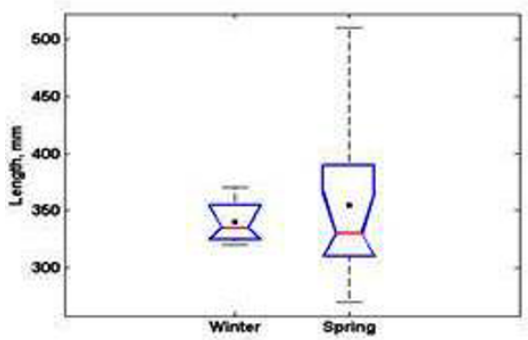

(b) L. synagris, Bertioga (Autumn $n=4$; Winter $n=18$; Spring $n=5$; Summer $n=2$ )

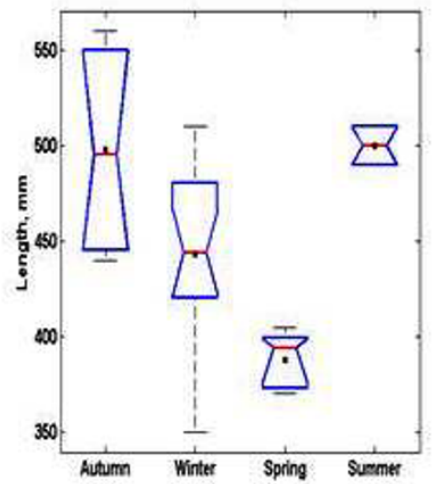

(d) O. chrysurus, P. Sauipe

(Winter $n=57$; Spring $n=9$ )

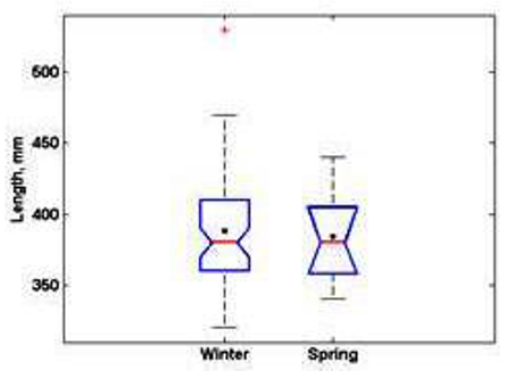

(f) L. synagris, Paraty (Winter $n=3$; Spring $\mathrm{n}=\mathbf{3 1}$ )

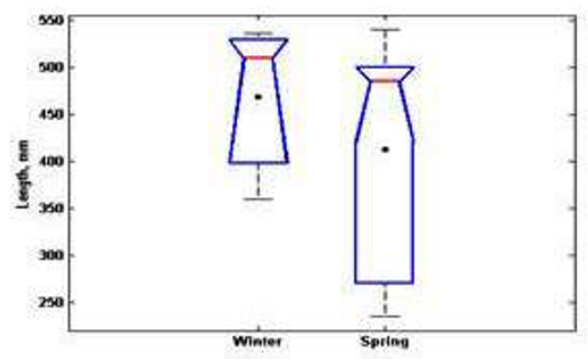

Figure 7 Length distributions for species of the Lutjanidae family in different seasons of the year. Samples were taken in April 2008January 2009. black dot - mean value; top and bottom of lines - maximum and minimum values; above and under the line of blue figure - 75 th and 25th percentiles; red line - median; red cross - stray values.

does not know about the reproductive behavior of species). Considering the site where there is the highest occurrence and diversity of species of snappers on artisanal landings (Porto Sauípe Bahia), we noticed that knowledge on reproduction of snappers is higher among the old fishermen (averaging an age of $63, \mathrm{n}=11$ ); fishermen that do not know about snapper reproduction aged an average of 48 years old $(n=3)$. Therefore, suggestive periods for fishing snappers, and for closed season, avoiding thus reproductive periods, could be obtained by interviewing especially older fishers, that could help directly in management. 


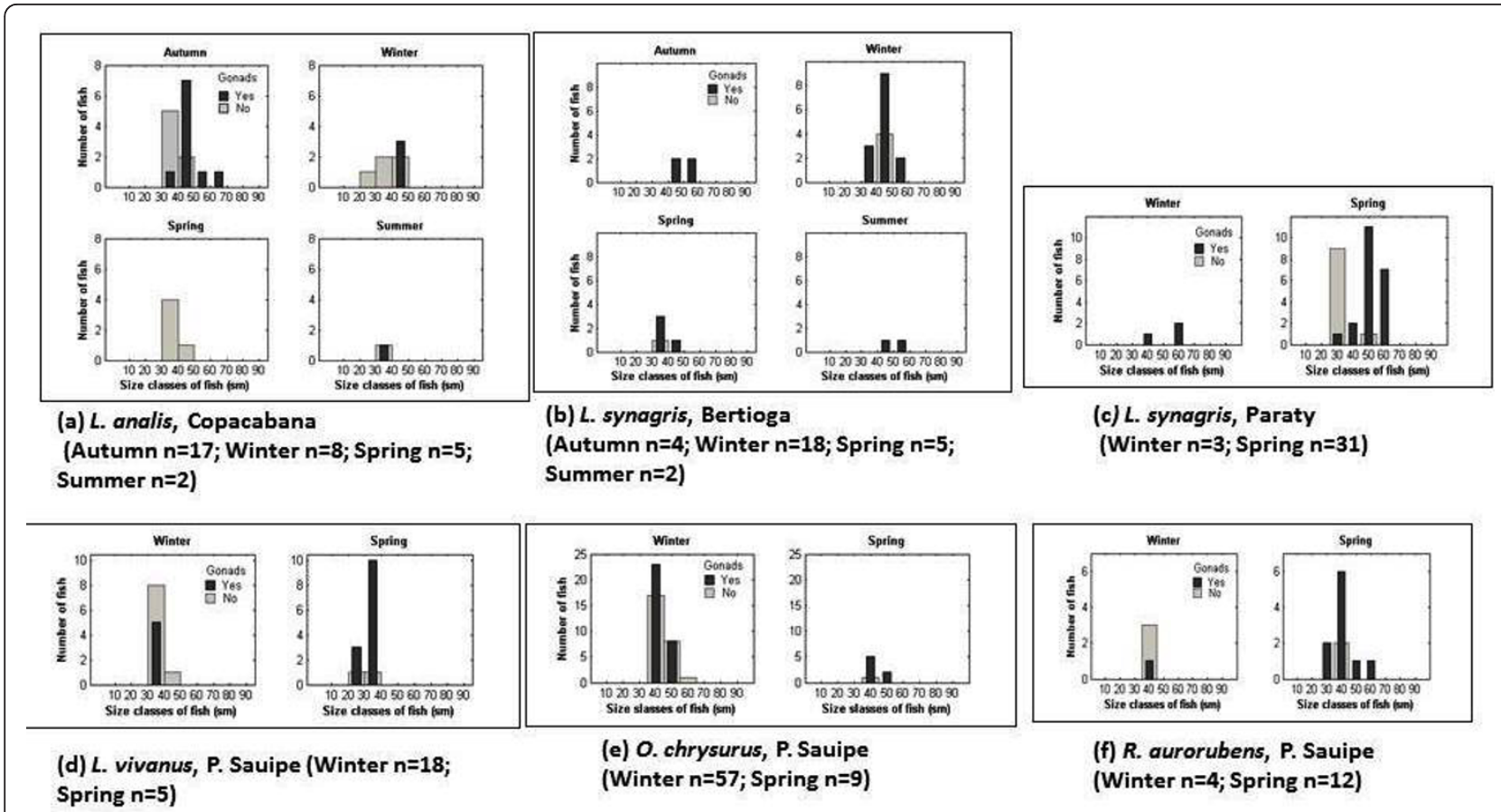

Figure 8 Seasonal variation in distribution over size classes with or without visible gonads of snappers caught by artisanal fisheries.

It is important to address that, in spite of the significance of artisanal fishing in Brazil [23], and the importance of snappers and other reef fishes as commercial catches $[13,14]$ there is no legislation that regulates the size or number of the snappers that are caught. Additionally, the economic importance of snappers has led them to a status of exploited populations [14]. After consulting the federal legislation of IBAMA (http:// www.pescamadora.com.br/peixes_agua_salgada/tamanho_minimos_peixes_agua_salgada.pdf) we did not find any minimum threshold for catching snappers (Lutjanidae) in Brazil. What we do not know, however, is why the fish in Copacabana (Rio) and in NE Brazil (Riacho doce) were being caught so early. It may be due to the impact of artisanal fisheries, or it is possible that artisanal fisheries are only able to catch the fish that have been not captured by industrial fisheries.

\section{Local knowledge, management, and target fish}

The similarity between the information from the relatively scarce biological literature on snappers (Lutjanidae) and the information provided by fishermen was striking. Fish and crustaceans were the main food items of snappers according to the literature as well as the fishermen [10,62-67].

According to the interviewed fishermen, many snappers spawn in the spring and live in rocky substrates (Table 5). The results of our biological survey indicated that snappers have a higher GSI, which indicates reproductive activity, and show more individuals with visible eggs in the spring in Porto Sauípe (Table 3). These results reinforce the need to include local fishermen in biological research. As knowledge on fish reproduction in the scientific literature is generally scarce, the clues fishermen give can be useful for defining periods of closed fishing activities. Most results on snappers identifies the spring and the summer as spawning periods. A suggestion given by this study would be to identify, together with fishermen, the spawning periods more claearly per species of snapper. It worth paraphrasing Thresher (1984: 121)[68]:

Spawning for most tropical snappers seems to occur over a large part of the year and may take place year-round for many species. Spawning peaks, however, generally coincide with periods of warm water temperature, though not necessarily the warmest part of the year. In the Western Atlantic, for example, spawning reaches a peak in the summer near the northern limits of the family's range (refs, not cited here), but peaks in spring or its bimodal with peaks in the spring and fall in the tropics.

Finally, besides the importance of the spring and summer as reproductive seasons for snappers at the studied sites along the Brazilian coast, some snappers form spawning aggregations, such as the Lane snapper, L. analis [69] important to consider for the management 
Table 3 Percent of snappers with visible eggs in different periods of the year ${ }^{1}$

\begin{tabular}{|c|c|c|c|c|c|c|c|c|}
\hline Period & $\begin{array}{l}\text { L. analis } \\
\text { Copacabana }\end{array}$ & $\begin{array}{l}\text { L. synagris } \\
\text { Bertioga }\end{array}$ & $\begin{array}{l}\text { L. synagris } \\
\text { Maceio }\end{array}$ & $\begin{array}{l}\text { L. vivanus } \mathrm{P} \text {. } \\
\text { Sauipe }\end{array}$ & $\begin{array}{l}\text { O. chrysurus P. } \\
\text { Sauipe }\end{array}$ & $\begin{array}{l}\text { R. aurorubens P. } \\
\text { Sauipe }\end{array}$ & $\begin{array}{l}\text { L. synagris, } \\
\text { Paraty }\end{array}$ & Total \\
\hline \multirow[t]{2}{*}{ April } & $\underline{12.50^{*}}$ & & & & & & & 12.50 \\
\hline & 0 & & & & & & & 0 \\
\hline \multirow[t]{2}{*}{ May } & $\underline{0.00}$ & $\underline{50.00}$ & & & & & & 15.38 \\
\hline & 11.1 & 0 & & & & & & 7,7 \\
\hline \multirow[t]{2}{*}{ June } & $\underline{0.00}$ & $\underline{13.33}$ & & & & & & $\underline{11.11}$ \\
\hline & 0 & 0 & & & & & & 0 \\
\hline \multirow[t]{2}{*}{ July } & $\underline{0.00}$ & & & $\underline{28.57}$ & $\underline{1.75}$ & $\underline{0.00}$ & & $\underline{6.25}$ \\
\hline & 0 & & & 0 & 0 & 0 & & 0 \\
\hline \multirow[t]{2}{*}{ August } & & $\underline{0.00}$ & & & & & $\underline{0.00}$ & $\underline{0.00}$ \\
\hline & & 0 & & & & & 0 & 0 \\
\hline \multirow[t]{2}{*}{ September } & $\underline{0.00}$ & $\underline{20.00}$ & & & & & & 16.67 \\
\hline & 0 & 0 & & & & & & 0 \\
\hline \multirow[t]{2}{*}{ October } & $\underline{0.00}$ & & & $\underline{73.33}$ & $\underline{66.67}$ & $\underline{8.33}$ & & $\underline{45.00}$ \\
\hline & 0 & & & 6.7 & 22.2 & 41.7 & & 20.0 \\
\hline \multirow[t]{2}{*}{ November } & & & & & & & $\underline{38,70}$ & $\underline{38,70}$ \\
\hline & & & & & & & $38.7^{* *}$ & 38.7 \\
\hline \multirow[t]{2}{*}{ December } & $\underline{0.00}$ & 100.00 & & & & & & $\underline{50.00}$ \\
\hline & 0 & 0 & & & & & & 0 \\
\hline \multirow[t]{2}{*}{ January } & & & $\underline{73.33}$ & & & & & $\underline{73.33}$ \\
\hline & & & 26.7 & & & & & 26.7 \\
\hline \multirow[t]{2}{*}{ Autumn } & $\underline{5.88}$ & $\underline{50.00}$ & & & & & & 14.29 \\
\hline & 5.88 & 0 & & & & & & 4,8 \\
\hline \multirow[t]{2}{*}{ Winter } & $\underline{0.00}$ & $\underline{11.11}$ & & $\underline{28.57}$ & $\underline{1.75}$ & $\underline{0.00}$ & $\underline{0.00}$ & $\underline{6.73}$ \\
\hline & 0 & 0 & & 0 & 0 & 0 & 0 & 0 \\
\hline \multirow[t]{2}{*}{ Spring } & $\underline{0.00}$ & $\underline{20.00}$ & & $\underline{73.33}$ & $\underline{66.67}$ & $\underline{8.33}$ & $\underline{38,70}$ & $\underline{40.267}$ \\
\hline & 0 & 0 & & 6.7 & 22.2 & 41.7 & 38.7 & 26.0 \\
\hline \multirow[t]{2}{*}{ Summer } & $\underline{0.000}$ & $\underline{100.00}$ & $\underline{73.33}$ & & & & & $\underline{68.42}$ \\
\hline & 0 & 0 & 26.7 & & & & & 21.1 \\
\hline
\end{tabular}

${ }^{1}$ methods in [33] * in numerator - \% fish with visible eggs; in denominator - \% fish with male gonads (sperm or male).

*in 2 cases: sex not determined.

of the fisheries. This species is considered overexploited in Brazil, along with the other snappers L. synagris and O. chrysurus [54].

Fishermen from Porto do Sauípe showed the most knowledge of snappers' reproduction (Table 5), compared to fishermen from the other sites. Actually, these fishermen encouraged us to return to Porto do Sauípe to collect mature snappers during the correct season. We had one trip planned to Porto do Sauípe (July 2008), but information gathered from the interviews lead us to return to Porto do Sauípe in October 2008 because many fishermen stated that we would find mature fish at that time (Table 5). As the fishermen said, most of the fish with visible eggs were observed during October in Porto Sauipe (Appendix 1). From all of the sites, Porto do Sauípe was the one with the most available snappers [53], and snapper is a very common catch at this site. For fishermen in that area, snappers are their target species. This result shows that fishermen's knowledge is usually directed at target fish species.
Target species are the ones that are most manipulated (caught, cleaned, consumed and sold) by fishermen, and thus fishermen are more knowledgeable about these species. These results are important for considering ethnobiological studies in general, especially when trying to use local knowledge for fishery management. Improving the dialogue between fishermen and managers could be done by a co-management, engaging researchers in a careful discrimination of ethnobiological results, as already suggested [31]. It would be better to rely on the knowledge that fishermen have on the target fish, and not all fish in general, as an ethnobiological approach towards local management. Etnobiological approaches are necessary in data less fisheries, as are mostly artisanal fisheries in Brazil, and focusing on target species associated with fishermen turns data collected for management more reliable, since fishermen know more on target species.

Another important observation from our study was that fishermen possessed accurate, detailed knowledge 
Table 4 Stomach contents of the five species of snappers (Lutjanidae)

\begin{tabular}{|c|c|c|c|c|c|c|c|c|}
\hline & $\begin{array}{l}\text { L. analis, } \\
\text { Copacabana }\end{array}$ & $\begin{array}{l}\text { L. } \\
\text { synagris, } \\
\text { Bertioga }\end{array}$ & $\begin{array}{l}L . \\
\text { synagris, } \\
\text { Maceió }\end{array}$ & $\begin{array}{l}\text { L. } \\
\text { vivanus, } \\
\text { P. Sauipe } \\
\end{array}$ & $\begin{array}{l}\text { O. } \\
\text { chrysurus, } \\
\text { P. Sauipe } \\
\end{array}$ & $\begin{array}{l}\text { R. } \\
\text { aurorubens, } \\
\text { P. Sauipe }\end{array}$ & $\begin{array}{l}L . \\
\text { synagris, } \\
\text { Paraty }\end{array}$ & Total \\
\hline \multicolumn{9}{|l|}{ FISH } \\
\hline Sardine (Clupeidae) & 2 & & & & 1 & & & 3 \\
\hline cutlassfish (Trichiurus lepturus) & 1 & & & & & & & 1 \\
\hline $\begin{array}{l}\text { another fish (Haemulon, Scorpaena, } \\
\text { Eucinostomus, Diapterus volitans, Muraena sp., } \\
\text { Batrachoididae) }\end{array}$ & 6 & 7 & 3 & 3 & 12 & 11 & 5 & 47 \\
\hline \multicolumn{9}{|l|}{ CRUSTACEAN $^{2}$} \\
\hline shrimp (camarão) & & 7 & 3 & 2 & 1 & & 4 & 17 \\
\hline crab (caranguejo) & & 2 & 4 & & & & & 6 \\
\hline crab siri (siri) & & 5 & 3 & 3 & 7 & 1 & & 19 \\
\hline tamburutaca & & 2 & & & & & & 2 \\
\hline spanish slipper lobster (lagosta sapateira) & & 1 & & & & & & 1 \\
\hline crayfish (lagostim) & & & 1 & & & & & 1 \\
\hline another crustacean, rests & & 1 & 2 & & & & 4 & 7 \\
\hline \multicolumn{9}{|l|}{ MOLLUSCS } \\
\hline squid (lula) & 1 & & & & & & 1 & 2 \\
\hline mussel (mexilhão) & 1 & & & & & & & 1 \\
\hline shell of mussel (concha mexilhão) & 1 & & & & & & & 1 \\
\hline octopus (polvo) & 1 & & & & & & & 1 \\
\hline Rest of food & 6 & 6 & 4 & 8 & 8 & 6 & 8 & 46 \\
\hline Empty & 18 & 8 & 2 & 13 & 37 & 1 & 16 & 95 \\
\hline Total samples & 32 & 29 & 15 & 29 & 66 & 16 & 34 & 221 \\
\hline
\end{tabular}

of the diet of snappers because of the bait they use to catch these fish. The fishermen's knowledge correlated with data from the literature in that snappers feed basically on crustaceans and fish $[9,11,64,65,70]$. When observations given by fishermen (Table 5) are compared to our samples of stomach contents (Table 4), we found that we could rely on the fishermen's information regarding the diet of snappers. Diet is important for management purposes because, if some areas are to be preserved for fishing in the future, it is wise to determine the areas where the fish and crustaceans that snappers consume are found. Other studies have shown that coastal and freshwater fishermen have detailed knowledge of fish diets that largely agreed with the biological literature. The fishermen's knowledge could a useful resource for understanding the ecological interactions among exploited species and the effects of fishing on food chains $[34,37,71,72]$.

Fishermen's motivations for managing artisanal fisheries In terms of fishery management for reef fishes such as snappers, it is important to analyze the factors that motivate fishermen to catch fish species at early stages of maturity. Fishermen are often poor, rural people in Brazil, and they are dependent on fishing to sustain their families. This imposes the classic dilemma of how conservation could be made attractive to poor fishermen [23]. This dilemma is exacerbated by the reduction of fishing areas for artisanal fishermen, since they are squeezed between protected areas and sites used by industrial fisheries.

Artisanal fishermen from the coast of Brazil have been pressured in terms of their use of the marine space by environmental government agencies through the establishment of top-down conservation areas (without consultation or participation of locals or users) [73]. In addition, there is also conflict between industrial and artisanal fisheries competing for space [55]. These conflicts may even push artisanal fishermen to less conservative behaviors, since they can feel stimulated to obtain higher catches, or even to enter protected areas, before trawlers from industrial fisheries come into that areas[74].

Current literature has stressed the economic mechanisms behind the activities of fisheries, and in particular, the subsistence and sustainability of artisanal fisheries. For 
Table 5 Results of interviews performed with artisanal fishers ${ }^{1}$

\begin{tabular}{|c|c|c|c|c|c|c|}
\hline $\begin{array}{l}\text { Fishers and } \\
\text { Questions }\end{array}$ & $\begin{array}{l}\text { Bertioga }^{a} \mathrm{SE} \\
\text { Brazil N }=15\end{array}$ & $\begin{array}{c}\text { Copacabana }^{b} \text { SE } \\
\text { Brazil N }=13\end{array}$ & $\begin{array}{l}\text { Paraty SE Brazil (Praia Grande } \\
\text { and Ilha do Araújo) } \mathrm{N}=15\end{array}$ & $\begin{array}{l}\text { Porto Sauípe NE } \\
\text { Brazil } N=14\end{array}$ & $\begin{array}{c}\text { Riacho Doce } \\
\text { Maceió NE Brazil } \\
\mathrm{N}=13\end{array}$ & $\begin{array}{l}\text { Total } \\
\mathrm{N}=70\end{array}$ \\
\hline Fishers interviewed: & & & & & & Range \\
\hline Average Age & 50 & 49 & 46 & 60 & 40 & $40-60$ \\
\hline Minimum Age & 24 & 25 & 28 & 38 & 27 & $24-38$ \\
\hline Maximum Age & 80 & 74 & 63 & 73 & 61 & $61-80$ \\
\hline Average Time fishing & 32 & 28 & 35 & 48 & 22 & $22-48$ \\
\hline Minimum Time fishing & 10 & 12 & 24 & 29 & 11 & $10-29$ \\
\hline Maximum Time fishing & 50 & 55 & 60 & 65 & 50 & $50-65$ \\
\hline $\begin{array}{l}\text { Average Local } \\
\text { Residence Time }\end{array}$ & 27 & 35 & 45 & 59 & 40 & $27-59$ \\
\hline $\begin{array}{l}\text { Minimum Local } \\
\text { Residence Time }\end{array}$ & 13 & 10 & 28 & 38 & 27 & $10-38$ \\
\hline $\begin{array}{l}\text { Maximum Local } \\
\text { Residence Time }\end{array}$ & 66 & 62 & 63 & 73 & 61 & $61-73$ \\
\hline \multicolumn{7}{|l|}{$\frac{\text { What do snappers }}{\text { eat? }}$} \\
\hline$\overline{\text { Fish }}$ & 5 & 1 & 3 & 11 & 7 & 27 \\
\hline Sardines (Clupeidae) & 2 & 3 & 9 & 5 & 8 & 27 \\
\hline Manjuba (Engraulidae) & 1 & 6 & 2 & 1 & & 10 \\
\hline Other fish & & & Paraty:1 & $\begin{array}{l}\text { Mackerel: } 1 \\
\text { Agullha: } 1\end{array}$ & $\begin{array}{l}\text { Carapau: } 4 \text { Mackerel:1 } \\
\text { Saramunete: } 1\end{array}$ & 9 \\
\hline $\begin{array}{c}\text { Caranguejo/siri (Crabs) } \\
\text { (caranguejo/siri) }\end{array}$ & $1 /$ & & & $5 / 1$ & $/ 1$ & $6 / 2$ \\
\hline Shrimp & 6 & 8 & 14 & 5 & 2 & 35 \\
\hline Lobster & & & & 1 & & 1 \\
\hline Other crustacea & 1 & 2 & & & & 3 \\
\hline Marisco (mussels) & 3 & 4 & & 4 & & 7 \\
\hline Squid/Octopus & & $4 /$ & $2 /$ & $4 / 2$ & $1 / 1$ & $10 / 3$ \\
\hline Other mollusc & 2 & & & & & 2 \\
\hline Algae & 4 & & & & & 4 \\
\hline \multicolumn{7}{|l|}{$\frac{\text { Where do snappers }}{\text { live? }}$} \\
\hline Rocky substrate & 11 & 11 & 12 & 13 & 13 & 60 \\
\hline Cascalho (gravel) & 1 & 4 & 1 & & & 6 \\
\hline Beaches & & 1 & 13 & & & $1 / 4$ \\
\hline Coast & & 1 & & & & 1 \\
\hline Corals & & 1 & & 1 & 1 & \\
\hline Deep water & 3 & & & 2 & & \\
\hline \multicolumn{7}{|l|}{$\begin{array}{l}\text { When do snappers } \\
\text { are mature/spawn? }\end{array}$} \\
\hline Does not know & 11 & 7 & 7 & 3 & 8 & 36 \\
\hline Autumn & & & & & & 0 \\
\hline Winter & & 2 & 1 & & 1 & 4 \\
\hline Spring & 3 & & 1 & $10^{d}$ & & 14 \\
\hline Summer & 2 & 1 & 5 & 1 & 3 & 12 \\
\hline All year round & & & 1 & & 1 & 2 \\
\hline
\end{tabular}

${ }^{1}$ Sites: Bertioga, Copacabana, Paraty, Riacho Doce, Maceio and Porto Sauípe, Bahia, Brazil. For this study, we considered fishers with fishing experience and local residence of about 10 years.

${ }^{a} 9$ interviews excluded from our sample, ${ }^{b} 5$ interviews fishers excluded, ${ }^{c} 2$ interviews excluded (fishers with less that 10 years of fishing or local residence)

${ }^{d}$ To get a more detailed of answers in Porto do Sauípe, Bahia, 5 fishers explained gonads were mature by August, and that after September-October snappers spawn (11 fishers). 
Table 6 Fieldwork for interviews and to collect snappers in 2008 and $2009^{1}$

\begin{tabular}{|c|c|c|c|c|c|}
\hline Research site & $\begin{array}{l}\text { Trips/no. days for } \\
\text { snapper collection }\end{array}$ & Collection Period & $\begin{array}{l}\text { GPS Locations } \\
\text { (Google Earth) }\end{array}$ & $\begin{array}{l}\text { Total snappers } \\
\text { collected/spp }\end{array}$ & $\begin{array}{l}\text { Total interviews } \\
\text { with fishers }\end{array}$ \\
\hline Bertioga, SE Brazil & 10 (44 days) & $\begin{array}{l}\text { April 2008-January } \\
2009\end{array}$ & $\begin{array}{l}23^{0} 51^{\prime} 18^{\prime \prime} 46^{0} 08^{\prime} \\
20^{\prime \prime}\end{array}$ & 44/4 spp. & 24 \\
\hline Copacabana, Rio, SE Brazil & 12 (80 days) & $\begin{array}{l}\text { April } 2008 \text { - March } \\
2009\end{array}$ & $\begin{array}{l}22^{0} 58^{\prime} 15^{\prime \prime} 43^{0} 11^{\prime} \\
29^{\prime \prime}\end{array}$ & 35/3 spp. & 18 \\
\hline Paraty, SE Brazil & 02 (7 days) & $\begin{array}{l}\text { August and } \\
\text { November } 2008 .\end{array}$ & $\begin{array}{l}23^{0} 12^{\prime} 59^{\prime \prime} 44^{0} 43^{\prime} \\
04^{\prime \prime}\end{array}$ & 44/3 spp. & 15 \\
\hline $\begin{array}{l}\text { Porto Sauípe, Entre Rios, } \\
\text { Bahia, NE Brazil }{ }^{2}\end{array}$ & 02 (6 days) & $\begin{array}{l}\text { July and } \\
\text { October2008 }\end{array}$ & $\begin{array}{l}12^{0} 01^{\prime} 52^{\prime \prime} 37^{0} 39^{\prime} \\
40^{\prime \prime}\end{array}$ & 137/9 spp. & 14 \\
\hline $\begin{array}{l}\text { Riacho Doce, Maceió, } \\
\text { Alagoas, NE Brazil }\end{array}$ & 01 (04 days) & January 2009 & $9^{0} 33^{\prime} 50^{\prime \prime} 35^{\circ} 39^{\prime} 21^{\prime \prime}$ & 28/3 spp. & 15 \\
\hline
\end{tabular}

${ }^{1} \mathrm{~A}$ total of 288 snappers were collected in 142 days, and 86 fishermen were interviewed in the five fisheries. ${ }^{2} \mathrm{~A}$ second trip to Bahia was not initially planned. However, data from fishers on spawning periods collected in our first visit to Bahia made us planning for another trip, in order to double check on the gonad maturation of species. This second trip occurred in October 2008.

example, economic drivers are an important part of fishery management [75] (page 12163):

"For successful fisheries management, it will be necessary to move beyond the symptoms of fishing and to take into account drivers of harvest pressure that result in potentially significant ecosystem change. One step in this direction is to incorporate leading indicators for current and future impacts of fishing into management. What motivates fishermen?"

The access to resources, the importance of local rules, the equity in terms of access, along with the necessity for fishermen to sustain their families [23], are variables that must be considered in management propositions. Otherwise, the inshore reef fisheries will continue to be vulnerable marine fisheries. Two participatory categories can be drivers for fishermen to participate in management processes: the valorization of their local knowledge on fish species, as well as compensatory mechanisms, as can be 'payments for environmental services' (PES).

The first, the use of local knowledge, is a very stimulating process to fishermen, since they feel motivated to talk about fish and about the aquatic space (fishing spots, sites, islands). Finding mechanisms of obtaining data from fishermen, embedding them into processes of management, training them for monitoring processes, thus putting 'both knowledges' (scientific and local) as an interactive process, can motivate fishermen to be interested in conservation, and into co-managing the fishery.

The suggestion for compensatory mechanisms, such as payment for environmental services, could help driving the interest of fishermen towards conservation, thereby avoiding or reducing the current fishing of immature snappers. Payments for environmental services (PES) are voluntary transactions that involve well defined environmental services. These environmental services are purchased by a service buyer from a service provider if and only if the service provider secures the service provision (that is a condition) [76]. In our case, local fishermen could be paid to monitor fishing sites used by industrial fisheries and to provide information about the landing of snappers at their local fisheries, since fish landing data for snapper species is incomplete [22]. Fishermen could contribute to this data if they are included in management processes.

PES could be a practical road in order to have protected areas for biodiversity conservation and co-management processes. Mechanisms of payments for fishermen to avoid fishing in protected areas and to help monitoring those sites were suggested for other artisanal fishery in SE

Table 7 Values of weight distributions the most collected species of snappers

\begin{tabular}{llllllll}
\hline & $\begin{array}{l}\text { L. analis } \\
\text { Copacabana }\end{array}$ & $\begin{array}{l}\text { L. synagris } \\
\text { Bertioga }\end{array}$ & $\begin{array}{l}\text { L. synagris, } \\
\text { Maceió }\end{array}$ & $\begin{array}{l}\text { L. vivanus, } \\
\text { P. Sauipe }\end{array}$ & $\begin{array}{l}\text { O. chrysurus, } \\
\text { P. Sauipe }\end{array}$ & $\begin{array}{l}\text { R. aurorubens, } \\
\text { P. Sauipe }\end{array}$ & $\begin{array}{l}\text { L. synagris, } \\
\text { Paraty }\end{array}$ \\
\hline Mean (g) & 891.9 & 1174.1 & 340.0 & 496.6 & 488.6 & 528.8 & 1245,9 \\
St. error & 42.6 & 85.5 & 38.2 & 23.9 & 17.0 & 64.3 & 132,3 \\
Median & 900 & 1158 & 300 & 470 & 455 & 440 & 1625 \\
St. dev. & 237.4 & 460.3 & 147.8 & 128.5 & 138.5 & 257.3 & 771,2 \\
Interval & 1000 & 1620 & 600 & 610 & 780 & 1000 & 2350 \\
Min & 500 & 480 & 150 & 290 & 320 & 300 & 150 \\
Max & 1500 & 2100 & 750 & 900 & 1100 & 1300 & 2500 \\
N & 31 & 29 & 15 & 29 & 66 & 16 & 34 \\
\hline
\end{tabular}


Table 8 Values of lengths distributions for the most collected species of snappers

\begin{tabular}{llllllll}
\hline & $\begin{array}{l}\text { L. analis, } \\
\text { Copacabana }\end{array}$ & $\begin{array}{l}\text { L. synagris, } \\
\text { Bertioga }\end{array}$ & $\begin{array}{l}\text { L. synagris, } \\
\text { Maceió }\end{array}$ & $\begin{array}{l}\text { L. vivanus, } \\
\text { P. Sauipe }\end{array}$ & $\begin{array}{l}\text { O. chrysurus, } \\
\text { P. Sauipe }\end{array}$ & $\begin{array}{l}\text { R. aurorubens, } \\
\text { P. Sauipe }\end{array}$ & $\begin{array}{l}\text { L. synagris, } \\
\text { Paraty }\end{array}$ \\
\hline $\begin{array}{l}\text { Mean } \\
(\mathbf{m m})\end{array}$ & 401.0 & 444.7 & 282.0 & 337.9 & 387.6 & 351.3 & 417,8 \\
St. error & 7.3 & 10.3 & 8.6 & 6.4 & 4.5 & 14.8 & 19,4 \\
Median & 410 & 443 & 270 & 330 & 380 & 335 & 487,5 \\
St. dev. & 40.4 & 55.2 & 33.4 & 34.4 & 36.3 & 59.3 & 113.0 \\
Interval & 220 & 210 & 120 & 160 & 210 & 240 & 305 \\
Min & 300 & 350 & 240 & 250 & 320 & 270 & 235 \\
Max & 520 & 560 & 360 & 410 & 530 & 510 & 540 \\
N & 31 & 29 & 15 & 29 & 66 & 16 & 34 \\
\hline
\end{tabular}

Brazil (Arraial do Cabo, Rio de Janeiro), by using an already existent payment mechanism in Brazil, the 'defeso' [77]. The 'defeso' is a governmental payment for fishermen in periods of closed shrimp fishing. Such type of payment we suggest could be applicable for payments for fishermen avoiding closed protected areas, for example, or closed periods when some snapper species are spawning.

\section{Conclusions: management and research suggestions}

Artisanal fisheries are important in the commercial fisheries of tropical countries, especially in Brazil. Snappers are target species, having good commercial value, but are in relative danger of being overfished. Some of the species that are caught, such as Lutjanus synagris in Riacho Doce, Maceió, and Lutjanus analis in Copacabana, Rio de Janeiro, have been caught at sizes below the minimum maturity length.

A dilemma exists when facing conservation and tropical artisanal fisheries, since many fishermen are poor and depend upon fishing for their livelihoods. The other dilemma that runs against conservation, looking through fishermen lens, are trawlers that enter bays and coastal shallow areas, sweeping out the fishing spots, pushing artisanal fishermen to see conservation as a responsibility thrown out on their shoulders. Facing these dilemmas, managers should make use of mechanisms that integrate local fishermen's knowledge into fisheries management as proposed by previous surveys. In this study, we propose: 1) that local fishermen have viable knowledge of the diet of snappers and of their reproductive season, which could be used for management purposes in a dialogue process with managers and academics; 2) that such a dialogue should rely on target species because fishermen tend to have more knowledge on the commonly caught species; 3 ) that motivation should enhance strategies for conservation in countries were artisanal fishing is very relevant, and where impoverished people depend upon those resources. To deal with poverty, we propose the ecological-economic strategy of paying for environmental services. Such proposition was already given concerning the management of the Arraial

Table 9 Mean values of gonadosomatic index (GSI) for species of Lutjanidae (\%)

\begin{tabular}{|c|c|c|c|c|c|c|c|c|}
\hline Period & $\begin{array}{l}\text { L. analis } \\
\text { Copacabana }\end{array}$ & $\begin{array}{l}\text { L. synagris } \\
\text { Bertioga }\end{array}$ & $\begin{array}{l}\text { L. synagris } \\
\text { Maceió }\end{array}$ & $\begin{array}{l}\text { L. vivanus } \\
\text { P. Sauipe }\end{array}$ & $\begin{array}{l}\text { O. chrysurus } \\
\text { P. Sauipe }\end{array}$ & $\begin{array}{l}\text { R. aurorubens. } \\
\text { P. Sauipe }\end{array}$ & $\begin{array}{l}\text { L. synagris, } \\
\text { Paraty }\end{array}$ & Total \\
\hline April & $0.55 \pm 0.22$ & & & & & & & $0.55 \pm 0.22$ \\
\hline May & $0.15 \pm 0.04$ & $0.85 \pm 0.18$ & & & & & & $0.36 \pm 0.11$ \\
\hline June & $0.10 \pm 0.05$ & $0.52 \pm 0.14$ & & & & & & $0.45 \pm 0.13$ \\
\hline July & $0.09 \pm 0.04$ & & & $0.45 \pm 0.13$ & $0.25 \pm 0.03$ & $0.24 \pm 0.11$ & & $0.28 \pm 0.03$ \\
\hline August & & $0.22 \pm 0.12$ & & & & & $0.66 \pm 0.16$ & $0.44 \pm 0.13$ \\
\hline September & $0.05^{a}$ & $1.12 \pm 0.84$ & & & & & & $0.94 \pm 0.71$ \\
\hline October & $0.07 \pm 0.01$ & & & $1.37 \pm 0.25$ & $1.26 \pm 0.24$ & $0.45 \pm 0.09$ & & $0.94 \pm 0.13$ \\
\hline November & & & & & & & $1.93 \pm 0.27$ & $1.91 \pm 0.27$ \\
\hline December & $0.37 \pm 0.27$ & $4.04 \pm 0.16$ & & & & & & $2.21 \pm 1.07$ \\
\hline January & & & $3.58 \pm 0.46$ & & & & & $3.58 \pm 0.46$ \\
\hline Autumn & $0.34 \pm 0.11$ & $0.85 \pm 0.18$ & & & & & & $0.43 \pm 0.11$ \\
\hline Winter & $0.09 \pm 0.03$ & $0.47 \pm 0.12$ & & $0.45 \pm 0.13$ & $0.25 \pm 0.03$ & $0.24 \pm 0.11$ & $0.66 \pm 0.16$ & $0.32 \pm 0.03$ \\
\hline Spring & $0.07 \pm 0.01$ & $1.12 \pm 0.84$ & & $1.37 \pm 0.24$ & $1.26 \pm 0.24$ & $0.45 \pm 0.09$ & $1.93 \pm 0.27$ & $1.34 \pm 0.15$ \\
\hline Summer & $0.37 \pm 0.27$ & $4.04 \pm 0.16$ & $3.58 \pm 0.46$ & & & & & $3.29 \pm 0.43$ \\
\hline
\end{tabular}

\footnotetext{
${ }^{a}$ Standard error not possible to calculate - unique value.
} 
Table 10 P-values* for pairwise tests of seasonal data on (GSI) of Lutjanidae ${ }^{1}$

\begin{tabular}{|c|c|c|c|c|}
\hline \multicolumn{5}{|c|}{ Species, seasons and comparisons } \\
\hline \multicolumn{5}{|c|}{ (a) L. analis, Copacabana } \\
\hline & Winter & Spring & Summer & \\
\hline Autumn & 0.0796 & 0.0593 & 0.5942 & \\
\hline Winter & & 1 & 0.1161 & \\
\hline Spring & & & 0.0507 & \\
\hline \multicolumn{5}{|c|}{ (b) L. synagris, Bertioga } \\
\hline & Winter & Spring & Summer & \\
\hline Autumn & 0.0885 & 0.1416 & 0.0641 & \\
\hline Winter & & 0.5528 & 0.0232 & \\
\hline Spring & & & 0.2453 & \\
\hline \multicolumn{5}{|c|}{ (c) Comparison, of GSI values between Winter and Spring for four species between Winter and Spring } \\
\hline & L. vivanus, P. Sauipe & O. chrysurus, P. Sauipe & R. aurorubens, P. Sauipe & L. synagris, Paraty \\
\hline P-parameter & 0.0013 & 0.0003 & 0.1816 & 0.3778 \\
\hline
\end{tabular}

${ }^{1}$ using the Kruskall-Wallis statistical test). ${ }^{*}$ if the p-value is less than 0.01 (or 0.05 ) one can assume that the data are drawn from the same distribution.

do cabo fishery, in Rio de Janeiro [77]. Our suggestions are specified as follows:

1) Co-management of fishing sites could enhance the participation of artisanal fisheries in management processes and conservation. One hypothesis is that, if the major impact on snapper fisheries comes from industrial fishing and artisanal fisheries are getting the leftover fish, which are juveniles, then this approach could minimize overfishing. The co-management of reef areas (between fishermen and the environmental agencies, for example) seems an alternative since fishermen know about the fishing spots of snappers and have some relative knowledge on the reproductive period of snappers.

2) Management should be especially focused on mutton snapper (L. analis, vermelho-cióba or cióba) and lane snapper (L. synagris) because they have been appeared on landings at juvenile stages. We can suggest closed fishing seasons for these species, such as in the spring and part of the summer at Copacabana. Other closed seasons can be negotiated

Table 11 Fishing spots used by artisanal fisheries in the five research sites

\begin{tabular}{|c|c|c|c|c|}
\hline Research site & Data on fishing sites/spots & \multicolumn{3}{|c|}{ Spots and number of fishers citing the spot } \\
\hline Bertioga, SE Brazil & $\begin{array}{l}\text { From Andreoli (2008) interviews }(n=24) \text { and Alcatrazes is } \\
\text { confirmed in our snapper sample. }\end{array}$ & \multicolumn{3}{|c|}{$\begin{array}{l}\text { Alcatrazes Island (17 fishers), Montão de Trigo Island } \\
\text { (10) Queimada Grande Island ( } 7) \text {, and Laje de Santos } \\
\text { Island (3), the most mentioned sites. }\end{array}$} \\
\hline $\begin{array}{l}\text { Copacabana, Rio, SE } \\
\text { Brazil }\end{array}$ & From our collection. & \multicolumn{3}{|c|}{$\begin{array}{l}\text { Cagarras Island (most common in our sample), Laje } \\
\text { de Santo Antonio, and Angra dos Reis. }\end{array}$} \\
\hline \multirow[t]{10}{*}{ Paraty, SE Brazil } & $\begin{array}{l}\text { Marking of fishing spots using GPS Garmin, with the help of fishers } \\
\text { Alcides and Marquinhos, November } 2008 \text {. }\end{array}$ & $\begin{array}{l}\text { Cais da Praia } \\
\text { Grande }\end{array}$ & $23^{\circ} 09^{\prime} 06^{\prime \prime}$ & $44^{\circ} 41^{\prime} 48^{\prime \prime}$ \\
\hline & & $\begin{array}{l}\text { Ponta da Baleia - } \\
\text { Ilha do Araújo }\end{array}$ & $23^{\circ} 09^{\prime} 02^{\prime \prime}$ & $44^{\circ} 40^{\prime} 55^{\prime \prime}$ \\
\hline & & $\begin{array}{l}\text { Ponta da Rapada - } \\
\text { Ilha Rapada }\end{array}$ & $23^{\circ} 09^{\prime} 33^{\prime \prime}$ & $44^{\circ} 39^{\prime} 37^{\prime \prime}$ \\
\hline & & Iha dos Ganchos & $23^{\circ} 10^{\prime} 25^{\prime \prime}$ & $44^{\circ} 38^{\prime} 02^{\prime \prime}$ \\
\hline & & Laje do Fundo & $23^{\circ} 07^{\prime} 54^{\prime \prime}$ & $44^{\circ} 39^{\prime} 31^{\prime \prime}$ \\
\hline & & Laje Rasa & $23^{\circ} 07^{\prime} 17^{\prime \prime}$ & $44^{\circ} 39^{\prime} 13^{\prime \prime}$ \\
\hline & & Ilha dos Meros & $23^{\circ} 10^{\prime} 57^{\prime \prime}$ & $44^{\circ} 34^{\prime} 26^{\prime \prime}$ \\
\hline & & Laje dos Meros & $23^{\circ} 10^{\prime} 40^{\prime \prime}$ & $44^{\circ} 34^{\prime} 39^{\prime \prime}$ \\
\hline & & Laje do Sapê & $23^{\circ} 11^{\prime} 00^{\prime \prime}$ & $44^{\circ} 34^{\prime} 35^{\prime \prime}$ \\
\hline & & Laje dos Ganchos & $23^{\circ} 10^{\prime} 12^{\prime \prime}$ & $44^{\circ} 37^{\prime} 12^{\prime \prime}$ \\
\hline $\begin{array}{l}\text { Porto Sauípe, Entre Rios, } \\
\text { Bahia, NE Brazil }\end{array}$ & From an interview with the fisher Celinho (66 y. old). & \multicolumn{3}{|c|}{$\begin{array}{l}\text { All spots with } 140 \text { m deep or more (70 braças): } \\
\text { Seladinha, Ponta da Areia, Preto, Selada Grande, } \\
\text { Ronco da Caatinga, Sampelício, Caranha, Oco da } \\
\text { Galha, Verde, Meio da Vagem, Caça Lobo, Mancha } \\
\text { Grande, Amiúda, Caatinga, Verde da Caatinga, } \\
\text { Camburú, Verde do Camburú. }\end{array}$} \\
\hline
\end{tabular}


with fishermen from Porto do Sauípe, per species, since this is the the most productive site for catching snappers, compared to the other sites we studied.

3) Finally, processes for payments for environmental services are suggestions that could help fishers to manage resources. In Copacabana, Rio de Janeiro, there is an urgent need to manage the $L$. analis population; in Riacho Doce, Maceió, and in Porto do Sauípe, the diversity and importance of snapper in artisanal fisheries justify such an initiative. Payments for environmental services could be directed through fishing accords or agreements (a negotiation process that already occur in Brazil) (23). By incorporating payments for environmental services, fishermen could be motivated to help transform the top-down approach in Brazilian fisheries into a more participatory process that works toward the conservation of marine resources.

\section{Appendix 1 \\ Questionnaire Protocol \\ Questions on snappers:}

1) Which snappers occur here?

2) What they eat?

3) Where (substract) they live?

4) When they are mature? (gonads)

Questions about the fisherman:
1) Fisherman name
2) Age
3) Study Site
4) Number of years fishing
5) Number of years of residence

\begin{abstract}
Acknowledgements
We are thankful to FAPESP for providing grant funding (\# 07/58700-7 and 09/11154-3) that allowed us to study snappers and local knowledge. We are thankful to R. Caires and J. L. Figueiredo for reviewing the fish identifications in the stomach contents of snappers and to G. S. Melo, for reviewing the crustacean identifications in the stomach contents of snappers (MZUSP, Brazil). We extend thanks to E. Camargo (FIFO) for interviews in Copacabana and Porto do Sauípe. We thank referees of JEE for improving the clarity of the ideas and results shown in this study. Finally, we are grateful to CNPq, which allowed one of the authors to investigate ecological economics and its applications through a collaboration with P. May, CPDA, Rio de Janeiro
\end{abstract} (Post-Doc Senior Scholarship to AB/Productivity Scholarship).

\section{Author details}

${ }^{1}$ Fisheries and Food Institute (FIFO), UNISANTA, Santos, SP, Brazil. ${ }^{2}$ UNICAMP (Capesca and CMU, CP 6023, Campinas, SP), Brazil. ${ }^{3}$ CPDA-Rio de Janeiro (CNPq, PD), Brazil. " ECOMAR, UNISANTA, Santos, SP, 11045-040, Brazil.

${ }^{5}$ Institute for Nature Management, National Academy of Sciences of Belarus, 10 Fr. Skaryna Street, Minsk, 220114, Minsk, Belarus. ${ }^{6}$ Natural Resources Institute (University of Manitoba)Canada. ${ }^{7}$ Depto. Ecologia/UFRGS, CP 15007, 91501-970 Porto Alegre - RS, Brazil.

\section{Authors' contributions}

AB conceived the study, collected data in the fieldsites, organized, and analyzed data on snappers, besides writing the paper; SS organized and analyzed quantitatively part of the data collected; LGA collected data in Paraty site; LECO collected data in Paraty and Riacho Doce sites; MC collected data in Copacabana, CMM collected data in Riacho Doce, AGF and TBA collected data on Bertioga, and RAMS contributed in the methods and in analyzing results. All authors read and approved the final manuscript.

\section{Competing interests}

The authors declare that they have no competing interests.

Received: 2 November 2010 Accepted: 16 March 2011

Published: 16 March 2011

\section{References}

1. Evans RD, Russ GR: Larger biomass of targeted reef fish in no-take marine reserves on the Great Barrier Reef, Australia. Aquatic Conservation 2004, 14:505-519.

2. Jennings S, Polunin NVC: Impacts of predator depletion by fishing on the biomass and diversity of non-target reef fish communities. Coral Reefs 1997, 16:71-82, 1997

3. De Boer WF, Van Schie AMP, Jocene DF, Mabote ABP, Guissamulo A: The impact of artisanal fishery on a tropical intertidal benthic fish community. Environmental Biology of Fishes 2001, 61:213-229.

4. McClanahan TR, Mangi S: The effect of a closed area and beach seine exclusion on coral reef fish catches. Fisheries Management and Ecology 2001, 8:107-121.

5. Ruttenberg BI: Effects of artisanal fishing on marine communities in the Galápagos Islands. Conservation Biology 2001, 15:1691-1699.

6. Marko PB, Lee SC, Rice AM, Gramling JM, Fitzhenry TM, MCAlister JS, Harper GR, Moran AL: Mislabeling of a depleted reef fish. Nature 2004, 430:309-310.

7. Frédou T, Ferreira BP, Letournneur Y: A univariate and multivariate study of reef fishes of northeastern Brazil. ICES Journal of Marine Sciences 2006 63:883-896.

8. Costa PAS, Braga AC, Rocha LOF: Reef fisheries in Porto Seguro, eastern Brazilian coast. Fisheries Research 2003, 60:577-583.

9. Starck WA, Shroeder RE: Investigations on the Gray Snapper, Lutianus griseus University of Miami Press, Coral Gables, FL; 1971.

10. Froese R, Pauly D, Editors: FishBase World Wide Web electronic Publication; 2010 [http://www.fishbase.org]

11. Menezes NA, Fiqueiredo JL: Manual de Peixes Marinhos do Sudeste do Brasil. Teleostei [3] São Paulo: MZUSP/EDUSP; 1980, 1980.

12. Menezes NA, Figueiredo JL: Catálogo de espécies de Peixes Marinhos do do Brasil MZUSP/EDUSP: 2003.

13. Frédou T, Ferreira BP, Letourneur $Y$ : (a) Assessing the stocks of the primary snappers caught in Northeastern Brazilian reef systems. 1. Traditional modelling approaches. Fisheries Research 2009, 99:90-96.

14. Frédou T, Ferreira BP, Letourneur $Y$ : (b) Assessing the stocks of the primary snappers caught in Northeastern Brazilian reef systems. 2. A multi-fleet age-structured approach. Fisheries Research 2009, 99:97-105.

15. Vasconcellos M, Diegues AC, Sales RR: Limites e possibilidades na pesca artesanal. Brasília. IBAMA 2007.

16. Barroso LM: Regime alimentar do pargo (Lutjanus aya, Bloch, 1795) no Nordeste brasileiro. Boletim de Estudos da Pesca (SUDENE, Recife) 1965, 5:7-16.

17. Ivo CTC, Hanson AJ: Aspectos da biologia e dinâmica populacional do pargo Lutjanus purpureus Poey, no Norte e Nordeste do Brasil. Arquivos de Ciências do Mar (UFCE, Fortaleza) 1982, 22:1-41.

18. Fonteles-Filho AA, Ferreira FT: Distribuição geográfica da captura do pargo, Lutjanus purpureus Poey, e sua relação com fatores oceanográficos nas regiões Norte e Nordeste do Brasil. Boletim de Ciências do Mar (UFCE, Fortaleza) 1987, 45:1-23.

19. Rezende SM, Ferreira BP, Frédou T: A pesca de lutjanídeos no Nordeste do Brasil: histórico das pescarias, características das espécies e relevância para o manejo. Boletim Técnico Científico da CEPENE 2003, 11:257-270.

20. Rezende SM, Ferreira BP: Age, growth and mortality of dog snapper Lutjanus jocu (Bloch \& Schneider, 1801) in the northeast coast of Brazil. Brazilian Journal of Oceanography 2004, 52:107-121. 
21. Ivo CTC, Sousa MJB: Sinopse de informações sobre o pargo, Lutjanus purpureus Poey (Pisces: Lutjanidae), no Norte e Nordeste do Brasil. Arquivos de Ciências do Mar (UFCE, Fortaleza) 1988, 27:57-67, 1988.

22. Klippel S, Olavo G, Costa PAS, Martins AS, Peres MB: Avaliação dos estoques de Lutjanídeos da costa central do Brasil: análise de coortes e modelo preditivo de Thompson e Bell para comprimentos. In Pesca e Potenciais de exploração de recursos vivos na região central da ZEE Brasileira. Edited by: Costa ASP, Martins AS, Olavo G. Rio de Janeiro: Museu Nacional; 2005:83-98, 2005.

23. Begossi A: Small-scale fisheries in Latin America: management models and challenges. MARE 2010, 9:7-31.

24. Pauly D, Christensen V, Dlasgaard J, Froese R, Torres F Jr: Fishing down marine food webs. Science 1998, 279:860-3.

25. Jackson JBC, Kirby MX, Berger WH, Bjorndal KA, Botsford LW, Bourque BJ, Bradbury RH, Cooke R, Erlandson J, Estes JA, Hughes TP, Kidwell S, Lange CB, Lenihan HS, Pandolfi JM, Peterson CH, Steneck RS, Tegner MJ, Warner RR: Historical overfishing and the recent collapse of coastal ecosystems. Science 2001, 293:629-8.

26. Myers $\mathrm{R}$, Worm B: Rapid worldwide depletion of predatory fish communities. Nature 2003, 423:280-283.

27. Geoffrey H, Schlenker W: Sustainable fisheries. Nature 2008, 455:1044-1045.

28. Johannes RE: The case for data-less marine resource management: examples from tropical nearshore finfisheries. Trends in Ecology and Evolution 1998, 13:243-246.

29. Sadovy Y: The threat of fishing to highly fecund fishes. Journal of Fish Biology 59 (A) 2001, 90-108.

30. Johannes RE, Freeman MMR, Hamilton RJ: Ignore fisher's knowledge and miss the boat. Fish and Fisheries 2000, 1:257-271.

31. Silvano RAM, Valbo-Jorgensen J: Beyond fishermen's tales: contribution of fishers' local ecological knowledge to fish ecology and fisheries management. Environment, Development and Sustainability; 2008:10:657-675.

32. Ruddle K: Systems of knowledge: dialogue, relationships and process. Environment, Development and Sustainability 2000, 2:277-304, 2000.

33. Begossi A: Local knowledge and training towards management. Environment, Development, and Sustainability 2008, 10:591-603.

34. Silvano RAM, Silva AL, Cerone M, Begossi A: Contributions of Ethnobiology to the conservation of tropical rivers and streams. Aquatic Conservation: Marine and Freshwater Ecosystems 2008, 18:241-260.

35. Pinnegar JK, Engelhard GH: The ' shifting baseline' phenomena: a global perspective. Rev Fish Biol Fishes 2007, 18(1):1-16.

36. Begossi A, Silvano RAM: Ecology and Ethnoecology of dusky grouper, garoupa, [Epinephelus marginatus (Lowe, 1834)] along the coast of Brazil. Journal of Ethnobiology and Ethnomedicine 2008, 4:1:20.

37. Silvano RAM, Begossi A: What can be learned from fishers? An integrated survey of ecological knowledge and bluefish (Pomatomus saltatrix) biology on the Brazilian coast. Hydrobiologia 2010, 637-3, 18

38. Aswani S: Patterns of marine harvest effort in southwestern New Georgia, Solomon Islands: resource management or optimal foraging? Ocean \& Coastal Management 1998, 40:207-235.

39. Aswani S, Lauer M: Incorporating fishermen's local knowledge and behavior into geographical information systems (GIS) for designing marine protected areas in Oceania. Human Organization 2006, 65:81-102.

40. Cordell J: A sea of small boats Cambridge, MA: Cultural Survival; 1989.

41. Cordell J: Scaling up marine management: the role of protected areas Washington DC: The World Bank; 2006.

42. Johannes RE: Words of the lagoon Berkeley: University of California Press; 1981.

43. Ruddle K, Johannes RE: The Traditional Knowledge and Management of Coastal Systems in Asia and the Pacific/Jakarta UNESCO; 1985.

44. Ruddle K, Johannes RE: Traditional Marine Resource Management in the Pacific Basin: An Anthology/ Jakarta, UNESCO; 1990.

45. Hickey FR, Johannes RE: Recent evolution of village-based marine resource management systems. SPC Traditional Marine Resource Management and Knowledge Information Bulletin 2002, 14: [http://www.unesco.org/csi/wise/ indigenous/vanuatu.htm], condensed version; full version in.

46. Acheson JM: Capturing the Commons New England: University Press of New England; 2003.

47. Berkes F: Sacred Ecology New York: Routledge; 2008.

48. Begossi A: Cooperative and territorial resources: Brazilian artisanal fisheries. In The Commons Revisited: an Americas Perspective. Edited by:
Burger J, Norgaard R, Ostrom E, Policansky D, Goldstein B. Menlo Park, CA: Island Press; 2001:109-130.

49. Begossi A: Temporal stability in fishing spots: conservation and comanagement in Brazilian artisanal coastal fisheries. Ecology \& Society; 2006:11(1):5 [http://www.ecologyandsociety.org/vol11/iss1].

50. Diegues AC: In Enciclopédia Caiçara. Volume I. Edited by: São Paulo. Hucitec; 2002.

51. Marques JGW: Aspectos ecológicos na ecologia dos pescadores do complexo estuarino-lagunar de Mundaú-Manguaba, Alagoas Unicamp, Campinas: PhD Thesis; 2001

52. Ramires MS, Barrella W: Etnoictiologia dos Pescadores artesanais da Estação Ecológica Juréia-Itatins (São Paulo, Brazil). In Enciclopédia Caiçara, vol I. Edited by: Diegues AC. São Paulo: Hucitec-Nupaub; 2005:117-132.

53. Silvano RAM, Mac Cord P, Lima RV, Begossi A: When does this fish spawn ? Fishermen's local knowledge of migration and reproduction of Brazilian coastal fishes. Environmental Biology of Fishes 2006, 76:371-386.

54. REVIZEE: Relatório Executivo (Jablonksy, S., Coord). Avaliação do potencial sustentável de recursos vivos na Zona Econômica Exclusiva do Brasil Brasília: Ministério do Meio-Ambiente; 2006 [http://www.mma.gov.br/estruturas/205/ _publicacao/205_publicacao03022011100749.pdf].

55. Begossi A, Lopes PF, Oliveira LEC, Nakano H: Ecologia de Pescadores Artesanais da Baía da llha Grande São Carlos: Editora Rima; 2010.

56. Nehrer R, Begossi A: Fishing at Copacabana, Rio de Janeiro: local strategies in a global city. Ciência e Cultura 2000, 52:26-30.

57. Andreoli TB: Etnoecologia de Lutjanidae (vermelhos) em comunidade de pescadores de Bertioga (SP). Campinas, Brazil: Report TCC, PUCCAMP; 2008 [http://www.puc-campinas.edu.br/graduacao/ccsa/ciencia_infor/ monografias.asp].

58. Caillet GM, Love MS, Ebeling AW: Fishes: a field and laboratory manual on their structure, identification and natural history Illinois: Waveland Press, Inc; 1986.

59. Moura RL, Lindeman KC: A new species of snapper (Perciformes: Lutjanidae) from Brazil, with comments on the distribution of Lutjanus griseus and Lutjanus apodus. Zootaxa 2007, 1422:31-43.

60. Melo GAS: In Manual de identificação dos Brachyura (Caranguejos e Siris) do Litoral Brasileiro. Edited by: São Paulo. Plêiade; 1996.

61. IUCN Red List. [http://www.iucnredlist.org/].

62. Anderson WD: Lutjanidae. In The living marine resources of the Western Central Atlantic. Volume 3: Bony fishes part 2 (Opistognathidae to Molidae), sea turtles and marine mammals. Edited by: Carpenter KE. Rome: FAO; 2002:1479-1486, 2002.

63. Cocheret de la M, Pollux E, Nagelkerken BJA, Van Der Velde G: Diet shifts of Caribbean grunts (Haemulidae) and snappers (Lutjanidae) and the relation with nursery-to-coral reef migrations. Estuarine, Coastal and Shelf Science 2003, 57:1079-1089, 2003.

64. Duarte LO, García CB: Diet of the Lane Snapper, Lutjanus synagris (Lutjanidae) in the Gulf of Salamanca, Colombia. Caribbean Journal of Science 1999, 35:54-63, 1999.

65. Duarte LO, García CB: Diet of the Mutton Snapper Lutjanus analis (Cuvier) from the Gulf of Salamanca, Colombia, Caribbean Sea. Bulletin of Marine Science 1999, 65:453-465.

66. Rooker JR: Feeding Ecology of the schoolmaster snapper, Lutjanus apodus (Walbaum), from southwestern Puerto Rico. Bulletin of Marine Science 1995, 56:881-894.

67. Harrigan P, Zieman JC, Macko SA: The base of nutritional support for the gray snapper (Lutjanus griseus): an evaluation based on a combined stomach content and stable isotope analysis. Bulletin of Marine Science 1989, 44:65-77.

68. Thresher RE: Reproduction in Reef Fishes New Jersey: T.F. H. Publications; 1984.

69. Burton ML: Age, growth and mortality of mutton snapper, Lutjanus analis, from the east coast of Florida, with a brief discussion of management implications. Fisheries Research 2002, 59:31-51.

70. Mueller KW, Dennis GD, Eggleston DB, Wicklund Rl: Size-specific social interactions and foraging styles in a shallow water population of mutton snapper, Lutjanus analis (Pisces: Lutjanidae), in the Central Bahamas. Environmental Biology of fishers 1994, 40:175-188.

71. Silvano RAM, Begossi A: Ethnoichthyology and fish conservation in the Piracicaba River (Brazil). Journal of Ethnobiology 2002, 22:285-306.

72. Silvano RAM, Begossi A: Local knowledge on a cosmopolitan fish, ethnoecology of Pomatomus saltatrix (Pomatomidae) in Brazil and Australia. Fisheries Research 2005, 71:43-59. 
73. Begossi A, Brown D: Fisheries co-management experiences in Latin America and the Caribbean. In The Fisheries co-management experience Edited by: Wilson DC, Nielsen JR, Degnbol P. Dordrecht: Kluwer Academic Pub., Fish and Fisheries Series 26; 2003:135-152.

74. Begossi A: The use of optimal foraging theory to understand fishing strategies: a case from Sepetiba Bay (State of Rio de Janeiro, Brazil). Human Ecology 1992, 20:463-475.

75. Seth SA, Branch TA, Watson R: Global fishery developments patterns are driven by profit but not trophic level. PNAS 2010, 107:12163-12167.

76. Engel S, Pagiola S, Wunder S: Designing payments for environmental services in theory and practice: an overview of the issues. Ecological Economics 2008, 65:663-74.

77. Vinha V, May P, Begossi A: Payments to avoid overfishing: PES potential for the Arraial Cabo Resex in Brazil. Paper present at the XI Conference of the International Society for Ecological Economics Oldenburg/Bremen, Germany; 2010.

doi:10.1186/1746-4269-7-11

Cite this article as: Begossi et al.: Ethnobiology of snappers (Lutjanidae): target species and suggestions for management. Journal of Ethnobiology and Ethnomedicine 2011 7:11.

\section{Submit your next manuscript to BioMed Central} and take full advantage of:

- Convenient online submission

- Thorough peer review

- No space constraints or color figure charges

- Immediate publication on acceptance

- Inclusion in PubMed, CAS, Scopus and Google Scholar

- Research which is freely available for redistribution

Submit your manuscript at www.biomedcentral.com/submit 